\title{
Tools for Embedding and Assessing Sustainable Development Goals in Engineering Education
}

\author{
Fermín Sánchez-Carracedo ${ }^{1, *} \mathbb{C}$, Jordi Segalas ${ }^{1} \mathbb{D}$, Gorka Bueno $^{2}$, Pere Busquets ${ }^{3} \mathbb{(}$, Joan Climent ${ }^{1}$, \\ Victor G. Galofré ${ }^{1}$, Boris Lazzarini ${ }^{1}{ }^{(}$, David Lopez $\left.{ }^{4}{ }^{(}\right)$, Carme Martín ${ }^{1}$, Rafael Miñano ${ }^{5}{ }^{(D}$, \\ Estíbaliz Sáez de Cámara ${ }^{2}{ }^{\circledR}$, Bárbara Sureda ${ }^{1}\left(\mathbb{D}\right.$, Gemma Tejedor $^{1}{ }^{(0)}$ and Eva Vidal ${ }^{1}{ }^{\mathbb{D}}$ \\ 1 University Research Institute for Sustainability Science and Technology, Universitat Politècnica de \\ Catalunya-UPC-BarcelonaTech, 08034 Barcelona, Spain; jordi.segalas@upc.edu (J.S.); \\ juan.climent@upc.edu (J.C.); victor.garcia.galofre@upc.edu (V.G.G.); boris.lazzarini@upc.edu (B.L.); \\ carme.martin@upc.edu (C.M.); barbara.sureda@upc.edu (B.S.); gemma.tejedor@upc.edu (G.T.); \\ eva.vidal@upc.edu (E.V.) \\ 2 Faculty of Engineering Bilbao, University of the Basque Country (UPV/EHU), 48013 Bilbao, Spain; \\ gorka.bueno@ehu.eus (G.B.); estibaliz.saezdecamara@ehu.eus (E.S.d.C.) \\ 3 Department of Mining, Industrial and ICT Engineering, Universitat Politècnica de \\ Catalunya_UPC-BarcelonaTech, 08034 Barcelona, Spain; pere.busquets@upc.edu \\ 4 Department of Computer Architecture, Universitat Politècnica de Catalunya-UPC-BarcelonaTech, \\ 08034 Barcelona, Spain; david@ac.upc.edu \\ 5 Innovation and Technology for Development Center, Universidad Politécnica de Madrid-UPM, \\ 28040 Madrid, Spain; rafael.minano@upm.es \\ * Correspondence: fermin.sanchez@upc.edu
}

Citation: Sánchez-Carracedo, F; Segalas, J.; Bueno, G.; Busquets, P.; Climent, J.; Galofré, V.G.; Lazzarini, B.; Lopez, D.; Martín, C.; Miñano, R.; et al. Tools for Embedding and Assessing Sustainable Development Goals in Engineering Education. Sustainability 2021, 13, 12154. https://doi.org/10.3390/su132112154

Academic Editor: Jordi Colomer Feliu

Received: 19 September 2021

Accepted: 29 October 2021

Published: 3 November 2021

Publisher's Note: MDPI stays neutral with regard to jurisdictional claims in published maps and institutional affiliations.

Copyright: (c) 2021 by the authors. Licensee MDPI, Basel, Switzerland. This article is an open access article distributed under the terms and conditions of the Creative Commons Attribution (CC BY) license (https:// creativecommons.org/licenses/by/ $4.0 /)$.
Abstract: This paper presents three tools developed within the framework of the project EDINSOST2SDG, aimed at embedding and assessing the Education for Sustainable Development (ESD) in Engineering curricula. ESD is promoted through the introduction into engineering curricula of learning outcomes related to sustainability and, specifically, to the Sustainable Development Goals (SDG). The first tool, the "Engineering Sustainability Map", contains ESD-related learning outcomes that any engineering student should have acquired upon completion of their studies. These learning outcomes are described according to four sustainability competencies: (1) Critical contextualization of knowledge, (2) Sustainable use of resources, (3) Participation in community processes, and (4) Application of ethical principles. The second tool, the "Sustainability Presence Map" of a degree, shows the percentage of the presence in the curriculum of each sustainability competency. The calculation of the presence of each competency is based on the effective integration of the related learning outcomes into a specific curriculum. Respective data are provided by teachers responsible for the coordination of the different subjects of the degree, collected by means of a questionnaire. The third tool presented is a questionnaire aimed at measuring the level of ESD that students perceive they have acquired through each competency. The comparison of data resulting from the Sustainability Presence Map with the data from the student questionnaire is the first step that allows the effectiveness of embedding ESD in a degree to be determined, a proper learning assessment will confirm such effectiveness. The three tools presented in this work have undergone a validation process and are currently being used in a set of engineering degrees related to the EDINSOST2-SDG project. The results of the application of these tools are part of the future research work of the authors.

Keywords: education for sustainable development; education for sustainable development goals; education for sustainability; engineering sustainability map; sustainability presence map; sustainability assessment

\section{Introduction}

The responsibility and the critical role of universities in facing the challenges of sustainability has been recognized from different fields for decades. This is reflected 
in more than 30 international declarations, documents and initiatives that have been supported by more than 1400 higher education institutions [1-3]. This responsibility affects all dimensions of the university's mission (research, education, and knowledge transfer), but it also calls on the institutions themselves to include the criteria and values of sustainability in their strategies, plans and management [4-8].

The United Nations 2030 Agenda and the Sustainable Development Goals (SDG) [9] roadmap identifies the university as one of the relevant actors to carry out this process. Integrating Sustainable Development Goals in curricula is a critical mission for universities, because universities are in a unique position to provide this service to society, and because integrating SDG can bring benefits to universities themselves, such as new collaborations with external actors and expanding training fields, research, and innovation oriented towards the UNESCO 17 SDG $[5,10]$.

Sustainability Science promotes a specific approach to mobilizing and applying knowledge (https:/ / en.unesco.org/themes/social-transformations/most/sustainability-science accessed on 28 October 2021), and seeks to understand the fundamental nature of complex interactions between nature and society [11] from a systemic, transdisciplinary, and co-creative perspective [12]. It is based on the broad vision or worldview of a sustainable development, in which sustainability science and the SDG should be aligned and integrated. In November 2019, the 40th session of the UNESCO General Conference adopted a new global framework for Education for Sustainable Development (ESD) called "Education for Sustainable Development: Towards the Achievement of the SDG" or "ESD for 2030" [13]. The ESD for 2030 framework aims to expand the action of the United Nations Decade of ESD (2005-2014) and the Global Action Program (GAP) on ESD (2015-2019).

Numerous studies and reports on sustainability in the university show that the greatest barriers and difficulties for change are found in the field of teaching-learning [14-18]. The orientation of university curricula towards sustainability is still far from being achieved [19], because in order to mainstream ESD and to integrate SDG in the curricula, universities need to scale up existing successful activities and implement new types of actions that go beyond "teaching-learning as usual" [10]. However, academic programs do not usually cover all the dimensions of sustainability: social, environmental, and economic. In fact, most of the experiences are isolated, with low incidence in the development of educational plans, and they often do not reach all students [20,21].

The situation is similar in the field of engineering education $[4,15,22-24]$, and some studies even show that the social commitment of students decreases as they advance in their university careers [25-28]. In this context, the integration of ESD presents an even a greater challenge in engineering education. The 2030 Agenda has placed great hope in the role of science and technology for achieving the SDG. That is why it is essential for students of science and technology to integrate the SDG deeply into their training as future professionals and citizens.

Extensive work has been done in relation to the competencies to be developed in order to meet the challenges of sustainability, and therefore the SDG. A complete synthesis of these competencies is presented in the UNESCO guide, Education for Sustainable Development Goals: Learning Objectives [29], based on previous work [30-32]. Eight key competencies are presented as crucial for the advancement of sustainable development (see Table 1).

These key competencies are transversal and complement rather than replace the specific competencies of each professional and academic field. The UNESCO guide [29] constitutes an exhaustive work on the determination of learning objectives, topics, and learning approaches and methods for each of the UNESCO 17 SDG. 
Table 1. UNESCO Key Competencies and their relation to CRUE Competencies.

\begin{tabular}{ccccc}
\hline \multirow{2}{*}{ UNESCO Key Competencies } & \multicolumn{4}{c}{ CRUE Competencies } \\
\cline { 2 - 5 } & C1 & C2 & C3 & C4 \\
\hline Systems thinking & $\mathrm{x}$ & $\mathrm{x}$ & \\
\hline Anticipatory & $\mathrm{x}$ & $\mathrm{x}$ & \\
\hline Normative & & $\mathrm{x}$ & \\
\hline Strategic & & & $\mathrm{x}$ \\
\hline Collaboration & $\mathrm{x}$ & & $\mathrm{x}$ \\
\hline Critical thinking & & & \\
\hline Self-awareness competency & & $\mathrm{x}$ & \\
\hline Integrated problem solving & & & \\
\hline Note: $x$ indicates that there is a clear relation. & & & \\
\hline
\end{tabular}

In the context of Spain, in 2012 the Executive Committee of the Conference of Rectors of Spanish Universities (CRUE) approved four sustainability competencies regarded as essential in the curricula of higher education degrees. These competencies are defined in the "Guidelines for the Introduction of Sustainability in the Curriculum" [33]:

- C1: Critical contextualization of knowledge by establishing interrelations with social, economic, environmental, local and/or global problems.

- C2: Sustainable use of resources and prevention of negative impacts on the natural and social environment.

- C3: Participation in community processes that promote sustainability.

- C4: Application of ethical principles related to the values of sustainability in personal and professional behavior.

In the specific field of engineering, the Barcelona Declaration [34] from the International Conference on Engineering Education for Sustainable Development defines the competencies that engineering professionals should acquire to face the challenges of sustainability. These competencies are consistent and aligned with both UNESCO and CRUE competencies. Therefore, according to the Barcelona Declaration, today's engineers must be able to:

- Understand how their work interacts with society and the environment, locally and globally, in order to identify potential challenges, risks and impacts.

- Understand the contribution of their work in different cultural, social, and political contexts and take those differences into account.

- Work in multidisciplinary teams in order to adapt current technology to the demands imposed by sustainable lifestyles, resource efficiency, pollution prevention, and waste management.

- Apply a holistic and systemic approach to solving problems and the ability to move beyond the tradition of breaking reality down into disconnected parts.

- Participate actively in the discussion and definition of economic, social, and technological policies, to help redirect society towards more sustainable development.

- Apply professional knowledge according to deontological principles and universal values and ethics.

- Listen closely to the demands of citizens and other stakeholders and allow them to have a say in the development of new technologies and infrastructures.

Different accreditation agencies for engineering degrees [35-37] propose learning outcomes that are also aligned with sustainability competencies and recognize the importance of their development in engineering education. Some of these competencies are reflected in Table 2 [4]. 
Table 2. Learning outcomes established by engineering accreditation agencies. Selection of the authors.

\begin{tabular}{cc}
\hline Learning Outcomes & Sustainability Competencies \\
\hline $\begin{array}{c}\text { Knowledge and } \\
\text { understanding }\end{array}$ & $\begin{array}{c}\text { The ability to analyze societal and environmental aspects of } \\
\text { engineering activities. Such ability includes an understanding of the } \\
\text { interactions that engineering has with the economic, health, safety, } \\
\text { legal, and cultural aspects of society; the uncertainties in the } \\
\text { prediction of such interactions, and the concepts of sustainable } \\
\text { design and development and environmental stewardship [36]. }\end{array}$ \\
\hline Application & $\begin{array}{c}\text { The ability to design solutions for complex, open-ended engineering } \\
\text { problems and to design systems, components or processes that meet } \\
\text { specified needs, with the appropriate attention to health and safety } \\
\text { risks, applicable standards, and economic, environmental, cultural, } \\
\text { and societal considerations [36]. }\end{array}$ \\
\hline Ethics and values & $\begin{array}{c}\text { The ability to recognize ethical and professional responsibilities in } \\
\text { engineering situations and make informed judgments, which should } \\
\text { also consider the impact of engineering solutions in global, economic, } \\
\text { environmental, and societal contexts [35]. }\end{array}$ \\
\hline Working with others & $\begin{array}{r}\text { The ability to function effectively in national and international } \\
\text { contexts, as a member or leader of a team, which may be composed } \\
\text { of different disciplines and levels, and may use virtual } \\
\text { communication tools [37]. }\end{array}$ \\
\hline
\end{tabular}

It is worth highlighting that the essential aspects required to incorporate the ESD and the SDG in the university studies are not solely related to the introduction of new contents or new subjects in the curricula, which in general are already quite overloaded $[14,16,38]$. The change must involve the review and change of teaching and learning strategies, as well as the promotion of some key aspects, such as: (i) the development of a critical and holistic vision; (ii) problem solving and decision-making issues incorporating sustainability criteria; (iii) ethics and social responsibility; (iv) interdisciplinary projects among different areas and courses, and (v) incorporating other social actors in university education $[10,39,40]$. This change poses a significant challenge, as it implies breaking with reductionist thinking, working in silos, and ignoring uncertainty, and instead of which, starting to operate in a more systemic, collaborative, interconnected and responsible way.

To ensure that ESD initiatives reach all students, curricula must include a significant number of compulsory courses in which explicit sustainability competencies are developed, in addition to elective sustainability activities or courses [14,20,22,39,41]. This integration must be systematically planned, using transformative learning approaches, and developing activities in different courses throughout the academic program. A coordinated, coherent, and incremental sequence of competencies is necessary to ensure a deep and meaningful learning. The final objective is for sustainability competencies to be perceived as something necessary and intrinsic in the activity of an engineer, and therefore in university education in engineering as well [41-44].

To facilitate the embedding of sustainability in the current curricula of the Spanish university system, the EDINSOST1 project [28] drew up sustainability maps for three fields: Engineering, Education, and Business Administration and Management [45]. The development of sustainability maps was based on the sustainability competencies defined by [33]. The EDINSOST2-SDG initiative, which is a continuation of the EDINSOST1 project, aims at incorporating the SDG into education for sustainability in the same three fields. This article presents three tools generated in the EDINSOST2-SDG project, as well as the specific methodologies used to design them. These tools are intended to support curriculum design processes for teachers and teaching teams whose aim is to embed sustainability competencies and the SDG in the academic curricula in a systematic, complete, and coherent way. 


\section{Materials and Methods}

\subsection{Which SDG Learning Objectives Should Be Developed in Engineering Curricula}

The document "Education for Sustainable Development Goals: Learning Objectives", [29] defined 15 learning objectives for each of the UNESCO 17 SDG. Specific SDG' learning objectives were then classified using a three-level taxonomy: cognitive (C), socioemotional (S), and behavioral (B). For each SDG, five objectives were determined at each level of the taxonomy. Altogether, 255 learning objectives were defined through this process that according to the UNESCO should be developed at different educational levels, including higher education.

In the EDINSOST2-SDG project, the SDG-Learning Objectives are identified by the initial letter of the taxonomy level $(\mathrm{C}, \mathrm{S}, \mathrm{B})$, followed by a number from 1 to 5 . For example, the SDG2 C4 is the fourth cognitive objective of the SDG 2 (Zero Hunger).

Each of the 255 SDG-Learning Objectives was assigned to one of the following three categories:

- Objectives to be developed in (almost) all engineering curricula (ENG)

- Objectives that should be developed in one or more specific engineering curricula, but not in all of them (Any ENG)

- Objectives that should be developed in other university studies (other than engineering), in non-university studies or simply throughout life (Other).

The methodology that the project followed to assign each learning objective to one of the previous categories was the following:

1. The workforce, made up of the authors of this paper, was divided into four independent groups: A, B, C, and D.

2. Group A reviewed the 255 learning objectives and assigned each learning objective to one of the three described categories (ENG, Any ENG, Others). To avoid discrepancies due to possible changes in criteria produced during the assignment process, the process was conducted in two specific iterations: in the first iteration, a pre-assignment of the learning objectives to the categories was carried out and the assignment criteria were established, and in a second iteration the result of the first iteration was reviewed.

3. Groups B, C, and D then reviewed the work done by group A. SDG 1 to 6 were assigned to group B, SDG 7 to 12 to group C, and SDG 13 to 17 to group D.

4. Subsequently, the four groups met to discuss possible differences found in the criteria used and to determine the final allocation of the learning objectives. The result of the assignment is shown in Figure 1.

\begin{tabular}{|c|c|c|c|c|c|c|c|c|c|c|c|c|c|c|c|c|c|}
\hline \multirow[b]{2}{*}{$\begin{array}{l}\text { Learning } \\
\text { Objectives }\end{array}$} & \multicolumn{17}{|c|}{ SDG } \\
\hline & $\begin{array}{c}\text { SDG1 } \\
\text { No Poverty }\end{array}$ & $\begin{array}{l}\text { SDG2 Zero } \\
\text { Hunger }\end{array}$ & \begin{tabular}{|c}
$\begin{array}{c}\text { SDG3 Good } \\
\text { Health \& } \\
\text { Well-being }\end{array}$ \\
\end{tabular} & $\begin{array}{c}\text { SDG4 Quality } \\
\text { Education }\end{array}$ & $\begin{array}{c}\text { SDG5 Gender } \\
\text { Equality }\end{array}$ & $\begin{array}{c}\text { SDG6 Clean } \\
\text { Water \& } \\
\text { Sanitation } \\
\end{array}$ & $\begin{array}{c}\text { SDG7 } \\
\text { Affordable \& } \\
\text { Clean Energy } \\
\end{array}$ & $\begin{array}{c}\text { SDG8 Decent } \\
\text { Work\& Ec. } \\
\text { growth }\end{array}$ & $\begin{array}{c}\text { SDG9 } \\
\text { Industry, } \\
\text { Innov. \& } \\
\text { Infrastruct. }\end{array}$ & $\begin{array}{l}\text { SDG10 } \\
\text { Reduce } \\
\text { Inequality }\end{array}$ & \begin{tabular}{|c|} 
SDG11 \\
Sustainable \\
Cities \& \\
Community \\
\end{tabular} & \begin{tabular}{|c|} 
SDG12 \\
Responsible \\
Consumpt.\& \\
Production \\
\end{tabular} & $\begin{array}{l}\text { SDG13 } \\
\text { Climate } \\
\text { Action }\end{array}$ & $\begin{array}{c}\text { SDG14 Life } \\
\text { below Water }\end{array}$ & $\begin{array}{c}\text { SDG15 Life } \\
\text { on Land }\end{array}$ & \begin{tabular}{|c|} 
SDG16 \\
Peace, \\
Justice \& \\
Strong Inst.
\end{tabular} & $\begin{array}{c}\text { SDG17 } \\
\text { Partnership } \\
\text { for the Goals }\end{array}$ \\
\hline C1 & Other & Other & ENG & Other & Other & Other & ENG & ENG & ENG & ENG & ENG & Other & Other & Other & Other & Other & Other \\
\hline $\mathrm{C} 2$ & Other & Other & Other & Other & Other & Other & Any ENG & Other & ENG & ENG & Any ENG & ENG & Other & Other & Other & Other & ENG \\
\hline $\mathrm{C} 3$ & ENG & Other & Other & ENG & Other & Any ENG & ENG & Other & ENG & Other & Any ENG & ENG & ENG & Other & Any ENG & Other & Other \\
\hline$C 4$ & ENG & Any ENG & Other & ENG & Other & ENG & Any ENG & Other & ENG & ENG & Any ENG & ENG & Any ENG & Other & \begin{tabular}{|l} 
Any ENG \\
\end{tabular} & ENG & ENG \\
\hline $\mathrm{C5}$ & Other & Any ENG & Other & ENG & ENG & Any ENG & Other & Other & ENG & Other & Any ENG & ENG & Any ENG & Other & Any ENG & ENG & ENG \\
\hline S1 & Other & Any ENG & Other & Other & Other & Any ENG & ENG & Other & Other & ENG & ENG & Other & Any ENG & Other & Other & Other & Other \\
\hline S2 & Other & Any ENG & Other & Other & Other & Any ENG & Any ENG & Other & Other & Other & ENG & ENG & Other & Other & Other & Other & Other \\
\hline S3 & Other & Other & Other & Other & Other & Other & Any ENG & Other & Other & Other & Other & Other & ENG & Other & Other & Other & ENG \\
\hline 54 & Other & Any ENG & Other & Other & Other & Other & Other & Other & Other & Other & Other & Other & Other & Other & Other & ENG & Other \\
\hline S5 & ENG & Other & Other & Other & Other & Other & Any ENG & Other & Other & ENG & Other & ENG & Other & Other & Other & Other & Other \\
\hline B1 & ENG & Any ENG & Other & Other & Other & Other & Other & ENG & ENG & ENG & ENG & ENG & ENG & Other & Other & Other & ENG \\
\hline$B 2$ & Other & Any ENG & Other & Other & ENG & Other & ENG & Other & ENG & ENG & ENG & Other & Other & Other & \begin{tabular}{|l} 
Any ENG \\
\end{tabular} & Other & Other \\
\hline B3 & Other & Any ENG & Other & Other & Other & Other & Any ENG & ENG & ENG & ENG & Other & ENG & Any ENG & Other & Other & Other & Other \\
\hline$B 4$ & Other & Other & Other & Other & Other & Any ENG & Other & ENG & Other & ENG & ENG & ENG & Any ENG & Other & Any ENG & Other & Other \\
\hline B5 & ENG & Any ENG & Other & Other & Other & Other & Any ENG & ENG & ENG & Other & ENG & Other & ENG & Other & Other & Other & ENG \\
\hline
\end{tabular}

Figure 1. Classification of the SDG-Learning Objectives in the three defined categories: All Engineering-ENG (green), some Engineering-Any ENG (yellow) and others-Other (pink).

Figure 1 shows a matrix in which each column represents the 15 learning objectives of a specific SDG. The rows correspond to the learning objectives defined by UNESCO 
according to Cognitive (C1-C5), Socioemotional (S1-S5) and Behavioral (B1-B5) categories. The content of the matrix corresponds to the assignment of each learning objective to the corresponding category: ENG, Any ENG, and Others. A color code has been used to facilitate the reading of the matrix.

As can be appreciated in Figure 1, 68 of the 255 learning objectives must be developed in (almost) all Engineering curricula (26.7\%), and 35 objectives in some engineering degrees $(13.7 \%)$. In total, 103 learning objectives of the SDG (40.4\%) must be developed in the Engineering curricula. Note that these 103 learning objectives are not specific to engineering. They must be developed in engineering, but it is also possible (and desirable) that they also be developed in other disciplines (at least, a large part of them).

\subsection{The Engineering Sustainability Map}

The Engineering Sustainability Map (ESM) comprises the learning outcomes related to sustainability that Engineering students should have acquired at the end of their undergraduate studies.

The first objective of the EDINSOST2-SDG project is to design the sustainability map of the degrees involved in the project, which comprises engineering curricula. The map was drawn up on the basis of (1) the ESM previously designed by the EDINSOST1 project [45] and (2) the SDG-Learning Objectives that must be developed in all engineering curricula (highlighted in green in Figure 1).

The ESM represents a competency map [44], which develops for engineering degrees the sustainability competencies defined by CRUE [33]. The competency map is essentially a matrix integrating the set of learning outcomes, related to a specific competency, that graduates of a particular curriculum should have acquired at the end of their studies. In this map, the learning outcomes are classified using a learning taxonomy, represented in the columns of the matrix, while the rows of the matrix include the different competency units. Consequently, each cell of the matrix corresponds to a competency unit related to a specific level of the learning taxonomy and consists of one or more learning outcomes.

The ESM of the EDINSOST2-SDG project was designed following the same criteria that guided the design of the EDINSOST1 ESM:

- $\quad$ The four sustainability CRUE competencies of [33] were used as a starting point because they are the reference framework of the Spanish university system. However, these competencies are transversal to sustainability, and therefore exportable to other university systems.

- $\quad$ Each CRUE competency was analyzed by focusing on the three classic dimensions of sustainability (social, environmental, and economic), together with a "holistic" dimension.

- Whenever possible, only the holistic dimension was considered in order to obtain a more reduced ESM. This reduction is important because the fewer the number of cells in the ESM, the fewer the number of learning outcomes, and therefore the easier it will be to embed the ESM in a curriculum.

- For each CRUE's sustainability competency/sustainability dimension, a single competency unit was defined, which more precisely describes the part of the sustainability competency that corresponds to the Engineering degrees.

- As in the ESM of EDINSOST1, we used a simplified version of Miller's pyramid as the learning taxonomy [46]. This taxonomy consists of four levels: (1) Know, (2) Know how, (3) Demonstrate and, (4) Do. The two upper levels of Miller's pyramid (Demonstrate and Do) were grouped into a single level because it was considered that, in the field of engineering, similarities between the two levels are more prominent (although in the field of medicine, where Miller's pyramid was created, it is understandable to consider them as separate).

The methodology used to design the ESM of the EDINSOST2-SDG project is similar to that described in Section 2.1:

1. The workforce, consisting of the authors of this paper, was divided into four independent groups: A, B, C, and D. 
2. Group A reviewed the 68 learning objectives of the SDG that must be developed in all engineering degrees (ENG in Figure 1) and related them to the learning outcomes of the ESM of EDINSOST1. Three types of cases were identified: (1) some SDGlearning objectives were described quite precisely by one or more learning outcomes of the ESM EDINSOST1; (2) some SDG-Learning Objectives showed a relationship with one or more learning outcomes of the ESM EDINSOST1 (in general, the SDGLearning Objectives are stated in a very generic way, while the learning outcomes of the ESM EDINSOST1 are highly oriented to the curricula engineering); and (3) some SDG-Learning Objectives were not related to any of the ESM EDINSOST1 learning outcomes.

3. For the learning objectives belonging to cases (1) and (2), the learning outcomes of the ESM were rewritten so that the relationship between both was more direct. For the objectives belonging to case (3), one or more new learning outcomes were introduced in the map. When necessary, the corresponding learning outcome was rewritten. Nonetheless, the ESM presents some learning outcomes that are not related to any objective learning SDG, although they are related to some SDG. The process was carried out in two iterations: in the first iteration, a pre-allocation between SDGLearning Objectives and learning outcomes was carried out and the allocation criteria were set; in a second iteration, the results of the first iteration were reviewed, and the learning outcomes were rewritten.

4. Groups B, C, and D reviewed the work done by group A. SDG 1 to 6 were assigned to group $B$, SDG 7 to 12 to group C, and SDG 13 to 17 to group D.

The four groups met to discuss the possible differences in criteria and to define the assignment and final drafting of the learning outcomes.

The researchers working on the EDINSOST2-SDG project come from different degrees and disciplines, consisting of Engineering, Education and Business Administration and Management. Researchers from the fields of Education and Business Administration and Management carried out a work similar to that described above but using the ESM as a starting point. The sustainability maps for the degrees in Engineering, Education and Business Administration and Management were first implemented and then grouped. First, each working group (Engineering, Education, and Business Administration and Management) reviewed the map of the other two fields to make the changes they considered appropriate to the sustainability map of their own field. Subsequently, several meetings were held between representatives of the three fields to discuss the differences and similarities between the three maps with the aim of achieving a map as cross-sectional as possible in each field. The reason for seeking transversality in sustainability maps is that one of the objectives of the EDINSOST2-SDG project is to build sustainability maps that can be easily exported to other degrees and fields not specifically included in the project. Finally, once the design of the three sustainability maps (one map for each field) was completed, the learning outcomes were codified, providing that the coding was also transversal. That is, similar learning outcomes in different maps have the same coding. The ESM obtained for the Engineering Degrees is presented in Section 3.

Based on the analysis of the degree of transversality of the three sustainability maps, the set of learning outcomes that should be developed in all higher education degrees was defined, which constitutes a subset of the learning outcomes of the ESM. This specific result is not presented in this paper because it goes beyond the objectives of this research work.

\subsection{Sustainability Presence Map}

The sustainability presence map of a degree provides information on the percentage of presence of each learning outcome of the ESM in the curriculum. This information allows the calculation of the presence of sustainability in a degree not only from the global point of view, but also from the perspective of each sustainability competency of the CRUE, each competency unit and each level of the learning taxonomy. 
In the EDINSOST1 project, sustainability presence maps of a set of engineering curricula were developed based on the learning guides of degree subjects. In some cases, complementary information provided by other official documents and by teachers of different subjects was also used. This information was collected by means of personal interviews. Extensive information on the results of the study, carried out in the 2018-2019 academic year, can be found in $[47,48]$.

The results obtained in the EDINSOST1 project suggested that subject teaching guides and other documents related to the curriculum are generally not up-to-date, and, thus often do not reflect the reality about the embedding of ESD. Consequently, the results obtained indirectly, namely through teaching guides and other formal documents, are not entirely reliable. The information obtained directly through personal interviews with teachers is much more accurate, but it is also more difficult to obtain due to the difficulty of interviewing a large number of teachers.

With the aim of obtaining reliable results in a less expensive way, EDINSOST2-SDG designed a questionnaire addressed to teachers responsible for degree subjects. This questionnaire directly asks to what extent each learning outcome included in the sustainability map is integrated/developed in the subject taught by a teacher. The questions are formulated in the third person and are focused on the students. In other words, the purpose of this questionnaire is not to investigate what the teacher does, but rather what the teacher considers that students learn through the activities they carry out during the course.

The information obtained from this questionnaire is much more up-to-date than that provided by subject learning guides and other curricular documents, but easier to obtain and presumably as useful as the information collected by personal interviews.

The questionnaire must accurately represent all learning outcomes of the sustainability map, and ensure a balance between precision, brevity, and clarity, which is not easy to achieve. With this purpose in mind and considering the 53 learning outcomes included in the ESM, those outcomes related to a specific topic were grouped into a single question with several sub-questions. The result obtained was a questionnaire consisting of 11 questions and 53 sub-questions. This grouping enabled the length of the survey to be shortened and simplified so that it could be answered in less than $15 \mathrm{~min}$. This is possible thanks to the fact that respondents only have to answer those questions related to the learning outcomes on which they specifically focus on their subjects. For each sub-question, teachers answer using a four-point Likert scale, to what extent the learning outcome is developed in their subject: "nothing", "little", "quite a bit", or "a lot". To facilitate this choice, the meaning of each adverb is briefly described at the beginning of the questionnaire:

- "Nothing" when not working on the subject.

- "Little" when working superficially.

- "Quite a bit" is the measurement between superficially and in-depth.

- "A lot" when working in depth.

This somewhat ambiguous description was preferred over a more precise description because learning outcomes are very different in nature, and it is very difficult to determine a single scale representing them all. For example, the time needed to develop "a lot" a learning outcome of the "Know" level may be less than the time necessary to develop "quite a bit" a learning outcome of the level "Demonstrate + Do".

The questionnaire design and validation process are described below:

1. A researcher in the engineering field, with previous experience of the EDINSOST1 project, carried out a first version of the engineering "presence questionnaire".

2. The rest of the EDINSOST2-SDG project researchers, including those from the fields of Education and Business Administration and Management, reviewed the questionnaire in a first iteration and suggested possible changes. For each question, its relevance (direct relationship with a learning outcome of the ESM) and clarity were analyzed.

3. After the first iteration of review, a second iteration was conducted and in which all the researchers of the project also participated. In this second iteration, the researchers made comments on the proposals of the rest of the team. 
4. A meeting was held with all the project researchers to discuss the results of the two review iterations and to put forward a proposal for the final questionnaire.

In order to prepare the questionnaire and carry out the validation process, a shared drive was used as a file repository and online collaborative word processor as the editing tool. Different examples of validation methodologies were consulted [49,50], not exclusively in the field of education for sustainability, in order to maximize the replicability of the tool. The involvement of all the project researchers in the preparation of the questionnaire and the transversality of the sustainability maps enabled the questionnaires addressed to teachers of the fields of Education and Business Administration and Management to be designed very quickly, once the engineering questionnaire became available. This fact shows that this experience would be easily replicable in other areas of knowledge.

\subsection{Analysis of the Learning Level of Sustainability of the Graduates: Design of the Questionnaire for Students}

The learning level of sustainability of graduates can be approximated by their perception of the sustainability competencies acquired, which can be measured by means of a questionnaire.

This tool has already been successfully tested in the project EDINSOST1 [51,52].

The experience acquired through the drafting and validation [53] of a questionnaire for the project EDINSOST1 enabled us to design and validate a questionnaire addressed to students for completion in a short time given the framework of project EDINSOST2-SDG.

The process of drawing up of this new questionnaire was the same as that described in Section 2.3. However, the questionnaire for students includes only 10 questions and 41 sub-questions in the form of first-person statements on the learning degree of students in each item. The questionnaire uses a 4-point Likert scale- "Nothing", "Little", "Quite a bit" and "A lot"-aimed at identifying the level of training that students believe they have acquired in the specific aspects surveyed. It also has the option Don't Know/No reply in case those surveyed are not sure of the answer or prefer not to answer.

Unlike the questionnaire for teachers, some sub-questions are related to more than a learning outcome of the ESM. The reason for this is that some learning outcomes are closely related to each other, and the experience of EDINSOST1 taught us that sometimes it can be difficult for students to differentiate between learning outcomes. Consequently, some learning outcomes belonging to the same competency unit and the same domain level, which are closely related, have been unified in a single sub-question.

\section{Results}

This section presents the three tools designed in EDINSOST2-SDG:

- Engineering Sustainability Map.

- Questionnaire for teachers for the creation of the Degree Sustainability Presence Map.

- Questionnaire for students on self-perception of their sustainability training.

These tools are intended to assist the embedding of sustainability competencies and SDG in academic curricula.

\subsection{Engineering Sustainability Map}

Table 3 presents the ESM designed in the EDINSOST2-SDG project. The map consists of 53 learning outcomes organized according to competencies, dimensions of sustainability, competency units and domain level, as explained below. The learning outcomes have been coded according to four identifiers.

- The first identifier $(\mathrm{C} 1, \mathrm{C} 2, \mathrm{C} 3, \mathrm{C} 4)$ refers to the sustainability competency defined by the CRUE.

- $\quad$ The second identifier (HO, EN, EC, SO) indicates whether the learning outcome refers to the holistic, environmental, economic, or social dimension of sustainability.

- The third identifier $(1,2,3)$ indicates the domain level in the learning taxonomy: 1-Know, 2- Know How or 3- Demonstrate + Do. 
- Finally, the fourth identifier details the order of the learning outcome within the ESM cell.

Table 3. ESM including the proposed coding for the learning outcomes.

\begin{tabular}{|c|c|c|c|c|c|}
\hline \multicolumn{6}{|c|}{ Engineering Sustainability Map } \\
\hline \multirow{2}{*}{$\begin{array}{l}\text { CRUE Sustainability } \\
\text { Competency }\end{array}$} & \multirow{2}{*}{ Dimension } & \multirow{2}{*}{ Competency Unit } & \multicolumn{3}{|c|}{ Domain Levels } \\
\hline & & & Know & Know How & Demonstrate + Do \\
\hline $\begin{array}{c}\text { C1: Critical } \\
\text { contextualization of } \\
\text { knowledge establishing } \\
\text { interrelations with social, } \\
\text { economic, and } \\
\text { environmental, local } \\
\text { and/or global problems. }\end{array}$ & Holistic & $\begin{array}{l}\text { 1. Learners have a historical and } \\
\text { contemporary perspective, and } \\
\text { understand the systemic nature of } \\
\text { environmental, social, and economic } \\
\text { problems, as well as their } \\
\text { interrelationships and future } \\
\text { challenges, both locally and globally. }\end{array}$ & $\begin{array}{l}\text { C1.HO.1.1 } \\
\text { C1.HO.1.2 } \\
\text { C1.HO.1.3 }\end{array}$ & C1.HO.2.1 & C1.HO.3.1 \\
\hline \multirow{4}{*}{$\begin{array}{l}\text { C2: Sustainable use of } \\
\text { resources and prevention of } \\
\text { negative impacts on the } \\
\text { natural and social } \\
\text { environment. }\end{array}$} & Environmental & $\begin{array}{l}\text { 2. Learners are able to detect and } \\
\text { analyze the environmental impact of } \\
\text { their professional activity and to } \\
\text { propose sustainable solutions. }\end{array}$ & $\begin{array}{l}\text { C2.EN.1.1 } \\
\text { C2.EN.1.2 }\end{array}$ & $\begin{array}{l}\text { C2.EN.2.1 } \\
\text { C2.EN.2.2 }\end{array}$ & $\begin{array}{l}\text { C2.EN.3.1 } \\
\text { C2.EN.3.2 } \\
\text { C2.EN.3.3 }\end{array}$ \\
\hline & Social & $\begin{array}{l}\text { 3. Learners are able to detect and } \\
\text { analyze the social impact of their } \\
\text { professional activity and to propose } \\
\text { sustainable solutions. }\end{array}$ & $\begin{array}{l}\text { C2.SO.1.1 } \\
\text { C2.SO.1.2 }\end{array}$ & $\begin{array}{l}\text { C2.SO.2.1 } \\
\text { C2.SO.2.2 }\end{array}$ & $\begin{array}{l}\text { C2.SO.3.1 } \\
\text { C2.SO.3.2 }\end{array}$ \\
\hline & Economic & $\begin{array}{l}\text { 4. Learners are able to manage the } \\
\text { material, financial and human } \\
\text { resources of the projects in their } \\
\text { professional field with sustainability } \\
\text { criteria to ensure their } \\
\text { economic viability. }\end{array}$ & $\begin{array}{l}\text { C2.EC.1.1 } \\
\text { C2.EC.1.2 }\end{array}$ & $\begin{array}{l}\text { C2.EC.2.1 } \\
\text { C2.EC.2.2 } \\
\text { C2.EC.2.3 }\end{array}$ & $\begin{array}{l}\text { C2.EC.3.1 } \\
\text { C2.EC.3.2 } \\
\text { C2.EC.3.3 } \\
\text { C2.EC.3.4 }\end{array}$ \\
\hline & Holistic & $\begin{array}{l}\text { 5. Learners are able to detect and } \\
\text { analyze the environmental, social, and } \\
\text { economic impact of their professional } \\
\text { activity and to propose, design, } \\
\text { organize and carry out } \\
\text { sustainable actions. }\end{array}$ & $\begin{array}{l}\text { C2.HO.1.1 } \\
\text { C2.HO.1.2 } \\
\text { C2.HO.1.3 } \\
\text { C2.HO.1.4 }\end{array}$ & $\begin{array}{l}\text { C2.HO.2.1 } \\
\text { C2.HO.2.2 } \\
\text { C2.HO.2.3 } \\
\text { C2.HO. } 2.4\end{array}$ & $\begin{array}{l}\text { C2.HO.3.1 } \\
\text { C2.HO.3.2 } \\
\text { C2.HO.3.3 } \\
\text { C2.HO.3.4 }\end{array}$ \\
\hline $\begin{array}{l}\text { C3: Participation in } \\
\text { community processes that } \\
\text { promote sustainability. }\end{array}$ & Holistic & $\begin{array}{l}\text { 6. Learners are capable of } \\
\text { participating in inclusive reflection } \\
\text { and decision-making processes with a } \\
\text { global citizenship perspective, and of } \\
\text { working from their professional field } \\
\text { on interdisciplinary and } \\
\text { transdisciplinary projects that guide } \\
\text { society towards } \\
\text { sustainable transitions. }\end{array}$ & $\begin{array}{l}\text { C3.HO.1.1 } \\
\text { C3.HO.1.2 } \\
\text { C3.HO.1.3 }\end{array}$ & С3.HO.2.1 & $\begin{array}{l}\text { C3.HO.3.1 } \\
\text { C3.HO.3.2 }\end{array}$ \\
\hline $\begin{array}{l}\text { C4: Application of ethical } \\
\text { principles related to the } \\
\text { values of sustainability in } \\
\text { personal and } \\
\text { professional behavior. }\end{array}$ & Holistic & $\begin{array}{l}\text { 7. Learners act in accordance with } \\
\text { ethical and deontological principles } \\
\text { related to the values of sustainability. }\end{array}$ & $\begin{array}{l}\text { C4.HO.1.1 } \\
\text { C4.HO.1.2 } \\
\text { C4.HO.1.3 } \\
\text { C4.HO.1.4 }\end{array}$ & $\begin{array}{l}\text { C4.HO.2.1 } \\
\text { C4.HO.2.2 }\end{array}$ & $\begin{array}{l}\text { C4.HO.3.1 } \\
\text { C4.HO.3.2 }\end{array}$ \\
\hline
\end{tabular}

Table 4 presents the definition of learning outcomes with the coding specified in the ESM shown in Table 1. 
Table 4. ESM Learning outcomes.

\begin{tabular}{|c|c|}
\hline Learning Outcomes & Description \\
\hline C1.HO.1.1. & $\begin{array}{l}\text { Know the concepts of Sustainability and Sustainable Development and its different dimensions } \\
\text { (environmental, social, and economic). }\end{array}$ \\
\hline C1.HO.1.2. & $\begin{array}{l}\text { Know the main causes, consequences and agents involved in social, economic and/or environmental } \\
\text { problems, both locally and globally. }\end{array}$ \\
\hline C1.HO.1.3. & $\begin{array}{c}\text { Know the solutions proposed for these problems (e.g., the Sustainable Development Goals of the } 2030 \\
\text { Agenda, IPCC reports). }\end{array}$ \\
\hline C1.HO.2.1. & $\begin{array}{c}\text { Critically reflect on the different dimensions of sustainability in the analysis of a situation related to their } \\
\text { professional field. }\end{array}$ \\
\hline C1.HO.3.1. & $\begin{array}{l}\text { To be able to relate a sustainability problem of a product or service in their professional field with the } \\
\text { methods and strategies used to address them. }\end{array}$ \\
\hline C2.EN.1.1. & $\begin{array}{l}\text { Know metrics (or tools) to measure the environmental impact of products and services related to their } \\
\text { professional field (e.g., environmental footprint, polluting emissions, resource/energy consumption, } \\
\text { environmental impact matrix, impact on biodiversity, waste generation, Directive 2014/95/EU for } \\
\text { non-financial reporting). }\end{array}$ \\
\hline C2.EN.1.2. & $\begin{array}{l}\text { Know strategies and/or technologies for reducing, reusing, and recycling natural resources and waste } \\
\text { related to the products and services in their professional field. }\end{array}$ \\
\hline C2.EN.2.1. & $\begin{array}{l}\text { Know how to use the appropriate metrics (or tools) to measure the environmental impact of the use of } \\
\text { products and services related to their professional field (e.g., environmental footprint, polluting } \\
\text { emissions, resource/energy consumption, environmental impact matrix, impact on biodiversity, waste } \\
\text { generation, Directive 2014/95/EU for non-financial reporting). }\end{array}$ \\
\hline C2.EN.2.2. & $\begin{array}{l}\text { To be aware of the environmental impact that products and services related to their professional field } \\
\text { have throughout their life cycle (extraction, production, use and end of life). }\end{array}$ \\
\hline C2.EN.3.1. & Consider environmental criteria in projects related to their professional field. \\
\hline C2.EN.3.2. & $\begin{array}{l}\text { Include in their projects indicators to estimate/measure the environmental impact (for example, } \\
\text { environmental footprint, polluting emissions, resource/energy consumption, environmental impact } \\
\text { matrix, impact on biodiversity, generation of waste, Directive 2014/95/EU for non-financial reporting). }\end{array}$ \\
\hline C2.EN.3.3. & $\begin{array}{l}\text { To be capable of contributing to the improvement of the environment and the prevention of harmful } \\
\text { impacts through their professional activity. }\end{array}$ \\
\hline
\end{tabular}

C2.SO.1.1.

Know metrics (or tools) for measuring and describing the social impact of products and services related to their professional field (for example, Social Life Cycle Analysis, ISO 26000, Directive 2014/95/EU for non-financial reporting).

ergonomics, accessibility, user experience, equity, diversity, common good, transparency, human rights, gender perspective, needs of the most vulnerable groups, discrimination, dignity, fight against corruption).

Know how to use the appropriate metrics (or tools) for measuring the social impact of products and services related to their professional field (e.g., Social Life Cycle Analysis, ISO 26000, Directive 2014/95/EU for non-financial reporting).

Include the direct and indirect consequences that products and services related to their professional field C2SO 2.2 have on safety, health, and social justice (e.g., ergonomics, accessibility, user experience, equity, diversity, common good, transparency, human rights, perspective of gender, needs of the most vulnerable groups, discrimination, dignity, fight against corruption).

C2.SO.3.1. Include indicators in their projects for measuring social impact (e.g., Social Life Cycle Analysis, ISO 26000, Directive 2014/95/EU for non-financial reporting).

Take into account in their projects and actions safety, health and social justice criteria (e.g., ergonomics,

C2.SO.3.2. accessibility, user experience, equity, diversity, common good, transparency, human rights, gender
perspective, needs of the most vulnerable groups, discrimination, dignity, fight against corruption).

C2.SO.3.2.
perspective, needs of the most vulnerable groups, discrimination, dignity, fight against corruption).

Know the basic concepts of resource management (material, financial and human) applicable to the C2.EC.1.1. management of projects in their professional field (e.g., fixed and variable costs, amortizations, budgets, Gantt charts).

Learn about methods (or tools) to estimate the economic viability of a project in their professional field C2.EC.1.2. (e.g., externalities analysis, CANVAS analysis, SWOT analysis, business plan, strategic plan, cost-benefit).

C2.EC.2.1. Analyze real cases of resource management. 
Table 4. Cont.

\section{Learning Outcomes}

C2.EC.2.2.

C2.EC.2.3.

C2.EC.3.1.

C2.EC.3.2.

C2.EC.3.3.

C2.EC.3.4.

\section{Description}

Understand the economic viability plan of a project in their professional field (e.g., externalities analysis,

CANVAS analysis, SWOT analysis, business plan, strategic plan).

Identify the economic consequences that a project or service in their professional field will have on society.

To be able to plan a project in their professional field (both short- and long-term) and to draw up a complete budget based on the material and human resources required.

To be able to carry out an economic viability plan for a project in their professional field (e.g., consider externalities, CANVAS analysis, SWOT analysis, business plan, strategic plan).

To be able to economically monitor the development of a project in their professional field and detect deviations from the initial planning.

To be able to monitor the financial management of a project in their professional field throughout its lifespan.

C2.HO.1.1.

C2.HO.1.2.

C2.HO.1.3.

C2.HO.1.4.

C2.HO.2.1.

C2.HO.2.2.

C2.HO.2.3.

C2.HO.2.4.

C2.HO.3.1.

C2.HO.3.2.

C2.HO.3.3.

C2.HO.3.4.

C3.HO.1.1.

C3.HO.1.2.

C3.HO.1.3.

C3.HO.2.1.

C3.HO.3.1.

C3.HO.3.2.

C4.HO.1.1.

C4.HO.1.2.
Know the direct and indirect consequences of the use of products and services related to their professional field for society, the economy, and the environment.

Know the strategic role that their profession plays in sustainability.

Know different economic approaches that promote sustainable development (e.g., circular economy, economy of the common good, social economy, green economy).

Know the roles, rights, and duties of the different agents (professionals, companies, legislation, clients, consumers, etc.) in the production and consumption of products and services related to their professional field.

To be able to critically assess the (beneficial/harmful) impact that products and services related to their professional field may have on society, the economy, and the environment.

Know how to analyze different alternatives of a product or service in their professional field to decide which is the most sustainable and evaluate to what extent it solves the problem posed

To be capable of critically assessing whether the economic viability of a project in their professional field is compatible with the environmental and social aspects of sustainability.

Know how to apply sustainability approaches to production, consumption (responsible consumption) and recycling.

To be capable of proposing sustainable projects in their professional field, considering environmental, economic, and social aspects.

To be capable of monitoring and dismantling a project in order to make it sustainable.

To be capable of contributing new ideas and solutions in a project in his/her professional field in order to improve the sustainability of products, processes or services.

To be able to select which indicators will be used to measure the sustainability of their projects in the different dimensions: environmental, social, and economic.

Know processes and projects in their professional field that consider the needs and expectations of stakeholders and have developed different degrees of interaction with them (information, consultation, participation, integration).

Learn about techniques and/or tools to promote collaboration and cooperation between the agents involved in a project or in a sustainability challenge (construction of scenarios, co-creation of knowledge, etc.).

Know the main interest groups and social, economic, and environmental agents related to the activity of their professional field.

Given a project in their professional field, to know how to collaborate with the agents involved to identify the needs and expectations of the different stakeholders, and to know how to assess the implications of these needs and expectations on the sustainability of the project.

To be capable of acting as an agent of change, participating from their professional field in reflection and decision-making processes that guide society towards sustainable transitions.

In a sustainability project or challenge, to be able to use techniques and/or tools to promote collaboration and cooperation in interdisciplinary and transdisciplinary contexts.

Know the main ethical issues related to sustainability in their professional field.

Know the ethical principles that underpin the values of sustainability (e.g., equality, justice, the precautionary principle, prevention of harm, responsibility for present and future generations, preservation of a healthy environment, social, economic, and environmental human rights). 
Table 4. Cont.

\begin{tabular}{|c|c|}
\hline Learning Outcomes & Description \\
\hline C4.HO.1.3. & $\begin{array}{c}\text { Know the concepts of social commitment and corporate social responsibility, their possibilities, } \\
\text { and limitations. }\end{array}$ \\
\hline C4.HO.1.4. & $\begin{array}{c}\text { Know the deontological principles of their profession and the laws and regulations related to } \\
\text { sustainability in their professional field. }\end{array}$ \\
\hline C4.HO.2.1. & $\begin{array}{c}\text { To be able to identify and critically assess the implications of ethical and deontological principles related } \\
\text { to the values of sustainability in their professional field. }\end{array}$ \\
\hline C4.HO.2.2. & $\begin{array}{l}\text { To be able to critically assess the responsible action of companies, as well as the implications that ethical } \\
\text { and deontological principles have in the projects, products, and services in their professional field. }\end{array}$ \\
\hline C4.HO.3.1. & $\begin{array}{l}\text { To be able to practice their profession taking into account the ethical principles related to the values of } \\
\text { sustainability (e.g., equality, justice, precautionary principle, prevention of damage, responsibility for } \\
\text { present and future generations, protection and restoration of a healthy environment, social, economic, } \\
\text { and environmental human rights). }\end{array}$ \\
\hline C4.HO.3.2. & $\begin{array}{c}\text { To be capable of actively participating in responsible action in the entities in which their profession } \\
\text { is developed. }\end{array}$ \\
\hline
\end{tabular}

Following the methodology defined in Section 2, learning outcomes have been related to the SDG-Learning Objectives-Cognitive (C1-C5), Socioemotional (S1-S5), and Behavioral (B1-B5)—proposed by UNESCO [29]. The relationships detected are shown in Figure 2.

As shown in Figure 2, some learning outcomes are related to as many as 4 SDGLearning Objectives. For example, the learning outcome C2.HO.1.3. is related to 4 learning objectives (C1, B1, B3, and B5) of SDG 8 and with learning objective C5 of SDG 9 and 17. Some SDG-Learning Objectives are related to as many as six learning outcomes (for example B2 of SDG 9 is related to C1.HO.2.1., C2.EN.2.1., C2.EN.3.2., C2.HO.3.1., C3.HO.2.1., C4.HO.2.1., and C4.HO. 2.2). In fact, SDG 9 and 12, referring to "Industry, Innovation, and Infrastructure", and "Responsible Consumption and Production", respectively, are those that present more matchings between the SDG-Learning Objectives defined by UNESCO and our proposal for learning outcomes of sustainability for engineering education (26 matches in the case of SDG 9 and 19 in the case of SDG 12). On the other hand, in three SDGs (SDG 2-Hunger Zero, SDG 12-Life Below Water, and SDG 15-Life on Land), no direct relationships were found between SDG-Learning Objectives and learning outcomes. This does not mean that engineering students should not work on these objectives, much less that engineering projects are not involved in the achievement of these SDG. It simply states that the SDG-Learning Objectives proposed by UNESCO in its dimensions B, C and SE do not necessarily have to form part of the sustainability competencies of all engineering degrees (there will be specific types of engineering, such as agronomic and forestry engineering, where for example these learning objectives of SDG14, SDG15, and SDG2 should be addressed). 


\begin{tabular}{|c|c|c|c|c|c|c|c|c|c|c|c|c|c|c|c|c|c|}
\hline \multirow{2}{*}{$\begin{array}{l}\text { Learning } \\
\text { outcomes/ } \\
\text { Learning } \\
\text { objectives }\end{array}$} & \multicolumn{17}{|c|}{ SDG } \\
\hline & 1 & 2 & 3 & 4 & 5 & 6 & 7 & 8 & 9 & 10 & 11 & 12 & 13 & 14 & 15 & 16 & 17 \\
\hline С1-но.1.1. & & & & & & & & & & & & & & & & & \\
\hline С1-Но.1.2. & C3 & & & $\begin{array}{l}\text { C4 } \\
\text { C5 }\end{array}$ & C5 & & $\mathrm{C} 1$ & $\mathrm{C} 1$ & C4 & & $\mathrm{C} 1$ & $\mathrm{C} 2$ & C3 & & & & C2 \\
\hline C1-HO.1.3. & & & & & & & & & & & & & & & & & \\
\hline C1-HO.2.1. & & & & & & & & & B2 & & $\mathrm{C} 1$ & & & & & & \\
\hline С1-HO.3.1. & & & & & & & B2 & & $\begin{array}{l}\text { C4 } \\
\text { B1 }\end{array}$ & B3 & & & & & & & \\
\hline C2.EN.1.1. & & & & & & & & & & & & & C3 & & & & C5 \\
\hline C2.EN.1.2. & & & & & & & C3 & & C1 & & & $\mathrm{C} 2$ & & & & & \\
\hline C2.EN.2.1. & & & & & & & $\mathrm{C} 3$ & & B2 & & & & & & & & \\
\hline C2.EN.2.2. & & & & & & $\mathrm{C} 4$ & C3 & & $\begin{array}{l}\mathrm{C} 1 \\
\mathrm{C} 2\end{array}$ & & & C2 & & & & & \\
\hline C2.EN.3.1. & & & & & & & & & & & B5 & B1 & B1 & & & & $\$ 3$ \\
\hline C2.EN.3.2. & & & & & & & B2 & & B2 & & B5 & B1 & B1 & & & & \\
\hline C2.EN.3.3. & & & & & & & B2 & B5 & & & & & B5 & & & & B1 \\
\hline C2-S0.1.1. & & & & & & & & & & $\mathrm{C} 2$ & & & & & & & C5 \\
\hline C2-so.1.2. & & & C1 & & & & & & C5 & & & C2 & & & & & \\
\hline C2-50.2.1. & C4 & & C1 & C3 & C5 & & & & $\begin{array}{l}\mathrm{C} 2 \\
\mathrm{C} 3\end{array}$ & $\begin{array}{l}\text { B1 } \\
\text { C1 } \\
\text { C4 }\end{array}$ & & C2 & & & & $\$ 4$ & \\
\hline C2-50.2.2. & & & & & C5 & & & & $\begin{array}{l}\mathrm{C} 1 \\
\mathrm{C} 2\end{array}$ & $\begin{array}{l}\text { C2 } \\
\text { S1 } \\
\text { S5 }\end{array}$ & & & & & & $\begin{array}{l}\text { C4 } \\
\text { C5 } \\
\text { S4 }\end{array}$ & \\
\hline C2-So.3.1. & & & & & B2 & & & & & $\begin{array}{l}\text { B2 } \\
\text { B4 }\end{array}$ & & & & & & & \\
\hline C2-So.3.2. & $\begin{array}{l}\text { B1 } \\
\text { B5 }\end{array}$ & & & & B2 & & & $\begin{array}{l}\text { B1 } \\
\text { B5 }\end{array}$ & & B4 & & B1 & & & & & $\$ 3$ \\
\hline C2.EC.1.1. & & & & & & & & & & & & & & & & & \\
\hline C2.EC.1.2. & & & & & & & & & & & & & & & & & \\
\hline C2.EC.2.1. & & & & & & & & & & & & & & & & & \\
\hline C2.EC.2.2. & & & & & & & & & & & & & & & & & \\
\hline C2.EC.2.3. & & & & & & & & & & & & & & & & & \\
\hline C2.EC.3.1. & & & & & & & & B4 & & & & & & & & & \\
\hline C2.EC.3.2. & & & & & & & & & & & & & & & & & \\
\hline C2.EC.3.3. & & & & & & & & B4 & & & & & & & & & \\
\hline C2.EC.3.4. & & & & & & & & B4 & & & & & & & & & \\
\hline
\end{tabular}

Figure 2. Cont. 


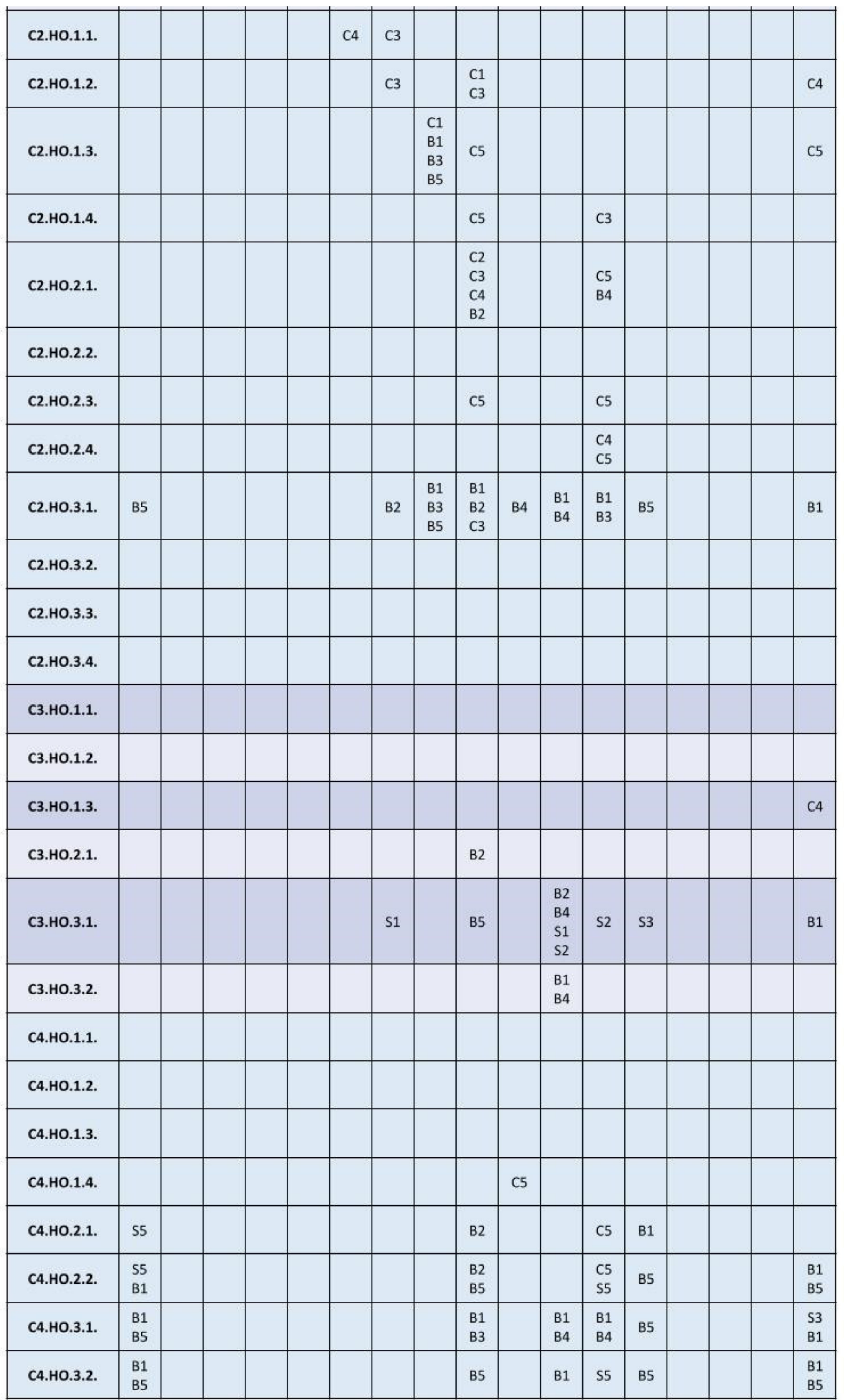

Figure 2. Relationship between ESM learning outcomes and SDG Learning Objectives. 


\subsection{Questionnaire for Teachers to Develop the Degree Sustainability Presence Maps}

The questionnaire for teachers, designed and validated to develop the Sustainability Presence Map, contains two blocks of questions. The first block refers to general data of the subject and its context, while the second block contains questions related to the learning outcomes of the ESM.

Metadata requested from the teaching staff in the first block of general questions are as follows:

- University

- Degree

- Subject

- Semester in which the subject is planned in the syllabus (1 to 8)

- Type of subject (Compulsory/Not compulsory or optional)

- Name of the person who answers the survey

- Email of the person answering the survey

- Activity carried out in the subject (Coordinator/Teacher)

- These metadata allow us to analyze which learning outcomes are being worked on in the different subjects, by semester, by degrees and by universities.

Table 5 details the questions in the second block of the questionnaire.

Table 5. Second block of questions of the teacher questionnaire to develop the Degree Sustainability Presence Map.

\section{Questions and Subquestions}

1. Regarding sustainability and its dimensions, learners:

(a) Know the concepts of Sustainability and Sustainable Development and its different dimensions (environmental, social, and economic).

(b) Reflect critically on the different dimensions of sustainability in the analysis of a situation related to their professional field.

2. Regarding sustainability and its dimensions, learners should:

(a) Know the main causes, consequences and agents involved in these problems, both locally and globally.

(b) Know about the proposed solutions (e.g., Sustainable Development Goals of the 2030 Agenda, IPCC reports).

(c) Are able to relate a problem of sustainability of a product or service in their professional field with the methods and strategies used to address them.

3. Regarding the metrics (or tools) to measure the environmental impact of the products and services related to their professional field (e.g., environmental footprint, polluting emissions, resources/energy consumption, environmental impact matrix, impact on biodiversity, waste generation, Directive 2014/95/EU for non-financial reporting), learners should:

(a) Know them.

(b) Know how to use them.

(c) Include in their projects indicators to estimate/measure the environmental impact.

(d) Take into account environmental criteria in projects related to their professional field.

(e) Know strategies and/or technologies for reducing, reusing and recycling natural resources and waste related to the products and services in their professional field.

(f) Be aware of the environmental impact that products and services related to their professional field have throughout their life cycle (extraction, production, use and end of life).

(g) Be capable of contributing to the improvement of the environment and the prevention of harmful impacts through their professional activity.

4. Regarding the metrics (or tools) that measure and describe the social impact of the products and services related to their professional field (e.g., Social Life Cycle Analysis, ISO 26000,

Directive 2014/95/EU for non-financial reporting), learners should:

(a) Know them.

(b) Know how to use them.

(c) Include in their projects indicators to estimate/measure the social impact. 
Table 5. Cont.

\section{Questions and Subquestions}

5. Regarding the concepts of health, safety and social justice related to their professional field (e.g., ergonomics, accessibility, user experience, equity, diversity, common good, transparency, human rights, gender perspective, needs of most vulnerable groups, discrimination, dignity, fight against corruption), learners should:

(a) Know them.

(b) Include the direct and indirect consequences that the products and services related to their professional field have on safety, health, and social justice.

(c) Take into account safety, health and social justice criteria in their projects and actions.

6. Regarding the management of resources (material, financial, and human) applicable in the management of projects in their professional field (e.g., fixed and variable costs, amortizations, budgets, Gantt charts), learners should:

(a) Know the basics.

(b) Analyze real cases of resource management.

(c) Be able to plan a project in their professional field (both short-and long-term) and to draw up a complete budget based on the material and human resources required.

(d) Be able to economically monitor the development of a project in their professional field and detect deviations from the initial planning.

(e) Be able to monitor the financial management of a project in their professional field throughout its lifespan.

7. Regarding the economic viability of the projects, learners should:

(a) Know methods (or tools) to estimate the economic viability of a project in their professional field (e.g., externalities analysis, CANVAS analysis, SWOT analysis, business plan, strategic plan, cost-benefit).

(b) Understand the economic viability plan of a project in their professional field.

(c) Be able to carry out an economic viability plan for a project in their professional field.

(d) Identify the economic consequences that a project or service in their professional field will have on society.

(e) Know the strategic role of their profession in sustainability.

(f) Know different economic approaches that promote sustainable development (e.g., the circular economy, the economy for the common good, the social economy, the ecological economy).

(g) Know the roles, rights and duties that different agents (professionals, companies, legislation, clients, consumers, etc.) have in the production and consumption of products and services related to their professional field.

8. Regarding the products and services related to their professional field, learners should:

(a) Know the consequences of their use, both direct and indirect, on society, the economy, and the environment.

(b) Be able to critically assess the impact (beneficial/harmful) they may have on society, the economy and the environment.

(c) Know how to analyze different alternatives to decide which are the most sustainable, and evaluate to what extent they solve the problem.

(d) Know how to apply sustainability approaches in production, consumption (responsible consumption) and recycling.

9. Regarding the projects in their professional field, learners should:

(a) Be able to select which indicators will be used to measure the sustainability of their projects in the different dimensions: environmental, social, and economic.

(b) Know how to critically assess whether the economic viability of a project in their professional field is compatible with the environmental and social aspects of sustainability.

(c) Be capable of proposing sustainable projects taking into account environmental, economic, and social aspects.

(d) Be capable of monitoring and dismantling a project to make it sustainable.

(e) Be able to contribute new ideas and solutions in a project to make it more sustainable, in such a way that the sustainability of products, processes or services is improved. 
Table 5. Cont.

\section{Questions and Subquestions}

10. Regarding the main interest groups and social, economic, and environmental agents related to the activity of their professional field, learners should:

(a) Know them.

(b) Know processes and projects in their professional field that consider the needs and expectations of stakeholders and have developed different degrees of interaction with them (information, consultation, participation, integration).

(c) Given a project in their professional field, know how to collaborate with the agents involved in order to identify the needs and expectations of the different stakeholders, and know how to assess the implications of these needs and expectations on the sustainability of the project.

11. Regarding the techniques and/or the tools to promote collaboration and cooperation between the agents involved in a project or in a sustainability challenge (construction of scenarios, co-creation of knowledge, etc.), learners should:

(a) Know them.

(b) In a sustainability project or challenge, be able to use them to promote collaboration and cooperation in interdisciplinary and transdisciplinary contexts.

(c) Be capable of acting as agents of change, participating from their professional field in reflection and decision-making processes that guide society towards sustainable transitions.

12. Regarding ethical and deontological principles, learners should:

(a) Know the ethical principles that underlie the values of sustainability (e.g., equality, justice, the precautionary principle, prevention of harm, responsibility with present and future generations, and preservation of a healthy environment, social, economic, and environmental human rights).

(b) Know the deontological principles of their profession and the laws and regulations related to sustainability in their professional field.

(c) Be able to identify and critically assess the implications of ethical and deontological principles related to the values of sustainability in their professional field.

(d) be able to practice their profession taking into account the ethical principles related to the values of sustainability (e.g., equality, justice, precautionary principle, prevention of damage, responsibility with present and future generations, protection and restoration of a healthy environment, social, economic, and environmental human rights).

(e) Know the main ethical issues related to sustainability in their professional field.

(f) Know the concepts of social commitment and corporate social responsibility, their possibilities, and limitations.

(g) Be capable of critically evaluating the responsible action of companies, as well as the implications that ethical and deontological principles have for the projects, products, and services of their professional field.

(h) Be capable of actively participating in responsible action in the entities where they develop their profession.

Figure 3 shows a matrix in which the questions of the questionnaire reported in Table 3 are related to the learning outcomes of the ESM and to the SDG. 


\begin{tabular}{|c|c|c|c|c|}
\hline Question & Subquestion & $\begin{array}{c}\text { Competency } \\
\text { Unit }\end{array}$ & $\begin{array}{l}\text { Learning } \\
\text { Outcome }\end{array}$ & SDG \\
\hline \multirow{2}{*}{1} & a & CU1 & C1.HO.1.1 & \\
\hline & $b$ & CU1 & C1.HO.2.1 & 9,11 \\
\hline \multirow{3}{*}{2} & a & CU1 & C1.HO.1.2 & $1,4,5,7,89,11,12,13,17$ \\
\hline & $b$ & CU1 & C1.HO.1.3 & \\
\hline & c & CU1 & C1.HO.3.1 & $7,9,10$ \\
\hline \multirow{7}{*}{3} & a & $\mathrm{CU} 2$ & C2.EN.1.1 & 13,17 \\
\hline & $b$ & $\mathrm{CU} 2$ & C2.EN.2.1 & 7,9 \\
\hline & c & CU2 & C2.EN.3.2 & $7,9,11,12,13$ \\
\hline & $d$ & CU2 & C2.EN.3.1 & $11,12,13,17$ \\
\hline & e & CU2 & C2.EN.1.2 & $7,9,12$ \\
\hline & $f$ & $\mathrm{CU} 2$ & C2.EN.2.2 & $6,7,9,12$ \\
\hline & g & CU2 & C2.EN.3.3 & $7,8,13,17$ \\
\hline \multirow{3}{*}{4} & a & CU3 & C2.SO.1.1 & 10,17 \\
\hline & $b$ & CU3 & C2.SO.2.1 & $1,3,5,9,10,12,16$ \\
\hline & c & CU3 & C2.SO.3.1 & 5,10 \\
\hline \multirow{3}{*}{5} & a & CU3 & C2.SO.1.2 & $3,9,12$ \\
\hline & b & CU3 & C2.SO.2.2 & $5,9,10,16$ \\
\hline & c & CU3 & C2.SO.3.2 & $1,5,8,10,12,17$ \\
\hline \multirow{5}{*}{6} & a & CU4 & C2.EC.1.1 & \\
\hline & $b$ & CU4 & C2.EC.2.1 & \\
\hline & C & CU4 & C2.EC.3.1 & 8 \\
\hline & $d$ & CU4 & C2.EC.3.3 & 8 \\
\hline & e & CU4 & C2.EC.3.4 & 8 \\
\hline \multirow{7}{*}{7} & a & CU4 & C2.EC.1.2 & \\
\hline & $b$ & CU4 & C2.EC. 2.2 & \\
\hline & c & CU4 & C2.EC.3.2 & \\
\hline & $d$ & CU4 & C2.EC.2.3 & \\
\hline & e & CU5 & C2.HO.1.2 & $7,9,17$ \\
\hline & $f$ & CU5 & C2.HO.1.3 & $8,9,17$ \\
\hline & $\mathrm{g}$ & CU5 & C2.HO.1.4 & 9,12 \\
\hline \multirow{4}{*}{8} & a & CU5 & C2.HO.1.1 & 6,7 \\
\hline & $\mathrm{b}$ & CU5 & C2.HO.2.1 & 9,12 \\
\hline & C & CU5 & C2.HO.2.2 & \\
\hline & $d$ & CU5 & C2.HO.2.4 & 12 \\
\hline
\end{tabular}

Figure 3. Cont. 


\begin{tabular}{|c|c|c|c|c|}
\hline \multirow{5}{*}{9} & a & CU5 & C2.HO.3.4 & \\
\hline & b & CU5 & C2.HO.2.3 & 9,12 \\
\hline & c & CU5 & C2.HO.3.1 & $1,7,8,9,10,11,12,13,17$ \\
\hline & $d$ & CU5 & C2.HO.3.2 & \\
\hline & e & CU5 & C2.HO.3.3 & \\
\hline \multirow{3}{*}{10} & a & CU6 & C3.HO.1.3 & 17 \\
\hline & b & CU6 & C3.HO.1.1 & \\
\hline & c & CU6 & C3.HO.2.1 & 9 \\
\hline \multirow{3}{*}{11} & a & CU6 & C3.HO.1.2 & \\
\hline & b & CU6 & C3.HO.3.2 & 11 \\
\hline & c & CU6 & C3.HO.3.1 & $7,9,11,12,13,17$ \\
\hline \multirow{8}{*}{12} & a & CU7 & C4.HO.1.2 & \\
\hline & b & CU7 & C4.HO.1.4 & 10 \\
\hline & c & CU7 & C4.HO.2.1 & $1,9,12,13$ \\
\hline & $d$ & CU7 & C4.HO.3.1 & $1,9,11,12,13,17$ \\
\hline & e & CU7 & C4.HO.1.1 & \\
\hline & $f$ & CU7 & C4.HO.1.3 & \\
\hline & g & CU7 & C4.HO.2.2 & $1,9,12,13,17$ \\
\hline & $\mathrm{h}$ & CU7 & C4.HO.3.2 & $1,9,11,12,13,17$ \\
\hline
\end{tabular}

Figure 3. Relationship between the questions and sub-questions of the teacher questionnaire to develop the Degree Sustainability Presence Map, the ESM learning outcomes, and the SDG.

\subsection{Questionnaire for Students about Their Preception of Sustainability Training}

The student questionnaire, which was designed and validated in order to determine know students' perception on their learning in sustainability during their university studies, is also divided into two blocks of questions. The first block includes five questions corresponding to general data, and the second block consists of 10 questions concerning the learning outcomes of the ESM.

The first block requires the following metadata:

- Gender

- Age

- Number of credits already obtained

- School

- Degree

The questionnaire will be distributed during several courses in all the universities participating in the project. The metadata will enable students' perceptions to be analyzed according to their respective educational center, degree studied and university, as well as the rest of the information collected in the first block of questions.

Table 6 details the questions in the second block of the questionnaire. 
Table 6. Second block of questions of the questionnaire for students about the perception of their learning in sustainability.

\section{Questions and Subquestions}

\section{General knowledge:}

(a) I know the concepts of Sustainability and Sustainable Development.

(b) I know different economic approaches that promote sustainable development (e.g., the circular economy, the economy of the common good, the social economy, the ecological economy).

(c) I know the roles, rights, and duties that different agents (professionals, companies, legislation, clients, consumers, etc.) have in the production and consumption of products and services related to my professional field.

2. Regarding the social, economic and/or environmental problems of today's society, both locally and globally:

(a) I know the main causes, consequences and agents involved in these problems.

(b) I know some international initiatives to address them: Sustainable Development Goals of the 2030 Agenda (SDG), Reports of the Intergovernmental Panel on Climate Change (IPCC), etc.

(c) I am capable of critically reflecting on the different dimensions of sustainability in the analysis of a situation related to my professional field.

(d) I am able to relate a problem of sustainability of a product or service in my professional field with the methods and strategies used to address them.

3. Regarding the environmental impact of products and services related to my professional field

(e.g., environmental footprint, polluting emissions, resource/energy consumption, environmental impact matrix, impact on biodiversity, generation of waste). (a) I know metrics (or tools) to measure environmental impact.

(b) I know strategies or technologies for the reduction, reuse, and recycling resources and waste.

(c) I am aware of the environmental impact that products and services related to my professional field have throughout their life cycle (extraction, production, use, and end of life).

(d) I know how to use appropriate metrics (or tools) to measure environmental impact.

(e) In projects in my professional field, I try to contribute to the improvement of the environment, taking into account environmental criteria and including indicators to measure environmental impact.

4. Regarding the consequences on health, safety and social justice of projects and actions in my professional field (e.g., ergonomics, accessibility, user experience, equity, diversity, common good, transparency, human rights, perspective of gender, needs of the most vulnerable groups, discrimination, dignity, fight against corruption).

(a) I know the basic concepts of health, safety, and social justice related to my professional field.

(b) I understand the direct and indirect consequences that products and services related to my professional field have on safety, health, and social justice.

(c) I take into account health, safety and social justice criteria in the projects and actions in my professional field.

5. Regarding indicators that measure and describe the social impact of products and services related to my professional field (e.g., social life cycle analysis, ISO 26000, Directive 2014/95/EU for non-financial reporting)

(a) I know metrics (or tools) that measure and describe the social impact of products and services related to my professional field.

(b) I know how to use metrics (or tools) to measure the social impact of products and services related to my professional field.

(c) I include indicators to measure the social impact in projects in my professional field.

6. Regarding the methods and tools to estimate the economic viability of a project (e.g., externalities analysis, CANVAS analysis, SWOT analysis, business plan, strategic plan, cost-benefit, etc.).

(a) I know methods (or tools) to estimate the economic viability of a project.

(b) I am able to understand the economic viability plan of a project or service in my professional field.

(c) I am able to carry out the economic viability plan of a project in my professional field.

(d) I know how to critically assess whether the economic viability of my project is compatible with the environmental and social aspects of sustainability. 
Table 6. Cont.

\section{Questions and Subquestions}

7. Regarding the management of resources (material, economic and human) applicable in project management:

(a) I know the basic concepts (e.g., fixed and variable costs, amortizations, budgets, Gantt charts).

(b) I know how to interpret the economic viability plan of a project.

(c) I know how to analyze real cases of project or service management and identify the economic consequences that these will have on society.

(d) I am capable of planning a project and of doing financial monitoring in all its phases.

8. Regarding projects, products and services related to my professional field.

(a) I know the strategic role that my profession has in sustainability and the consequences, direct and indirect, of the use of the products and services of my professional field in society, the economy, and the environment.

(b) I can analyze alternatives to decide which is the most sustainable and to what extent it solves the problem posed, and critically assess the impact of the selected alternative on society, the economy, and the environment.

(c) I know how to apply sustainability approaches in production, consumption, and recycling.

(d) I am able to monitor and dismantle a project to make it sustainable, and to select which indicators will be used to measure sustainability.

(e) I am able to propose sustainable projects in my professional field, or to contribute new ideas and solutions to make projects more sustainable, taking into account environmental, economic, and social aspects.

9. Regarding the interaction that occurs with other agents in the processes, activities and projects of my professional field:

(a) I know the main interest groups and social, economic, and environmental agents related to the activity of my professional field.

(b) I know processes and projects in my professional field that consider the needs and expectations of stakeholders and that have developed different degrees of interaction with them (information, consultation, participation, integration).

(c) I know techniques and/or tools for achieving different degrees of interaction (information, consultation, participation, integration).

(d) Given a project in my professional field, I know how to collaborate with the involved agents to identify the needs and expectations of the different stakeholders, and I know how to assess the implications of these needs and expectations for the sustainability of the project.

(e) In a sustainability project or challenge, I am able to use techniques and/or tools to promote collaboration and cooperation in interdisciplinary and transdisciplinary contexts.

(f) I am able to participate in my professional field in reflection and decision-making processes that guide society towards sustainable transitions.

10. Regarding the deontological principles of my profession and the ethical principles of sustainability (equity, justice, damage prevention, responsibility, and preservation of healthy environments, social, economic, and environmental human rights).

(a) With regard to sustainability in my professional field, I know the main ethical problems, the deontological and ethical principles, and the related laws and regulations.

(b) I know the concepts of social commitment and corporate social responsibility, as well as their possibilities and limitations.

(c) I am able to identify and critically assess the responsible action of companies, as well as the implications that ethical and deontological principles have on projects, products and services in my professional field.

(d) I feel qualified to exercise my profession in accordance with the ethical principles that underlie the values of sustainability and to actively participate in responsible action in the entities where I work.

Figure 4 shows a matrix where the questions of the questionnaire reported in Table 4 are related to the ESM learning outcomes. 


\begin{tabular}{|c|c|c|c|c|}
\hline Question & Subquestion & $\begin{array}{c}\text { Competency } \\
\text { Unit }\end{array}$ & $\begin{array}{l}\text { Learning } \\
\text { outcome }\end{array}$ & SDG \\
\hline \multirow{3}{*}{1} & a & CU1 & C1.HO.1.1 & \\
\hline & b & CU5 & C2.HO.1.2 & $7,9,17$ \\
\hline & c & CU5 & C2.HO.1.4 & 9,12 \\
\hline \multirow{4}{*}{2} & a & CU1 & C1.HO.1.2 & $1,4,5,7,8,9,11,12,13,17$ \\
\hline & b & CU1 & C1.HO.1.3 & \\
\hline & c & CU1 & C1.HO.2.1 & 9,11 \\
\hline & $d$ & CU1 & C1.HO.3.1 & $7,9,10$ \\
\hline \multirow{5}{*}{3} & a & CU2 & C2.EN.1.1 & 13,17 \\
\hline & b & CU2 & C2.EN.1.2 & $7,9,12$ \\
\hline & c & CU2 & C2.EN.2.2 & $6,7,9,12$ \\
\hline & $d$ & CU2 & C2.EN.2.1 & 7,9 \\
\hline & e & CU2 & $\begin{array}{l}\text { C2.EN.3.1, } \\
\text { C2.EN.3.2, } \\
\text { C2.EN.3.3 }\end{array}$ & $7,8,9,11,12,13,17$ \\
\hline \multirow{3}{*}{4} & a & CU3 & C2.SO.1.2 & $3,9,12$ \\
\hline & b & CU3 & C2.SO.2.2 & $5,9,10,16$ \\
\hline & c & CU3 & C2.SO.3.2 & $1,5,8,10,12,17$ \\
\hline \multirow{3}{*}{5} & a & CU3 & C2.SO.1.1 & 10,17 \\
\hline & $b$ & CU3 & C2.SO.2.1 & $1,3,5,9,10,12,16$ \\
\hline & c & CU3 & C2.SO.3.1 & 5,10 \\
\hline \multirow{4}{*}{6} & a & CU4 & C2.EC.1.2 & \\
\hline & $b$ & CU4 & C2.EC.2.2 & \\
\hline & C & CU4 & C2.EC.3.2 & \\
\hline & $d$ & CU4 & C2.EC.2.3 & 9,12 \\
\hline \multirow{4}{*}{7} & a & CU4 & C2.EC.1.1 & \\
\hline & b & CU4 & C2.EC.2.2 & \\
\hline & C & CU4 & $\begin{array}{l}\text { C2.EC.2.1, } \\
\text { C2.EC.2.3 }\end{array}$ & \\
\hline & $d$ & CU4 & $\begin{array}{l}\text { C2.EC.3.1, } \\
\text { C2.EC.3.2, } \\
\text { C2.EC.3.3, } \\
\text { C2.EC.3.4 }\end{array}$ & 8 \\
\hline
\end{tabular}

Figure 4. Cont. 


\begin{tabular}{|c|c|c|c|c|}
\hline \multirow{5}{*}{8} & a & CU5 & $\begin{array}{l}\text { C2.HO.1.1, } \\
\text { C2.HO.1.2 }\end{array}$ & $6,7,9,17$ \\
\hline & $b$ & CU5 & $\begin{array}{l}\text { C2.HO.2.1, } \\
\text { C2.HO.2.2 }\end{array}$ & 9,12 \\
\hline & c & CU5 & $\mathrm{C} 2 . \mathrm{HO} .2 .4$ & 12 \\
\hline & $d$ & CU5 & $\begin{array}{l}\text { C2.HO.3.2, } \\
\text { C2.HO.3.4 }\end{array}$ & \\
\hline & e & CU5 & $\begin{array}{l}\text { C2.HO.3.1, } \\
\text { C2.HO.3.3 }\end{array}$ & $1,7,8,9,10,11,12,13,17$ \\
\hline \multirow{6}{*}{9} & a & CU6 & C3.HO.1.3 & $8,9,17$ \\
\hline & $\mathrm{b}$ & CU6 & C3.HO.1.1 & \\
\hline & c & CU6 & C3.HO.1.2 & \\
\hline & $d$ & CU6 & C3.HO.2.1 & 9 \\
\hline & e & CU6 & C3.HO.3.2 & 11 \\
\hline & $f$ & CU6 & C3.HO.3.1 & $7,9,11,12,13,17$ \\
\hline \multirow{4}{*}{10} & a & CU7 & $\begin{array}{l}\text { C4.HO.1.1, } \\
\text { C4.HO.1.2, } \\
\text { C4.HO.1.4 }\end{array}$ & 10 \\
\hline & $b$ & CU7 & C4.HO.1.3 & \\
\hline & c & CU7 & $\begin{array}{l}\text { C4.HO.2.1, } \\
\text { C4.HO.2.2 }\end{array}$ & $1,9,12,13,17$ \\
\hline & D & CU7 & $\begin{array}{l}\text { C4.HO.3.1, } \\
\text { C4.HO.3.2 }\end{array}$ & $1,9,11,12,13,17$ \\
\hline
\end{tabular}

Figure 4. Relationship between the questions of the student questionnaire and the ESM learning outcomes.

\section{Discussion}

Ensuring education for sustainability in university training is a required responsibility of university curriculum designers. This work aims to facilitate sustainability embedding in Engineering education and has focused on the design of tools that enable (1) the definition of what learning outcomes engineering students must achieve through the Engineering Sustainability Map, and (2) a diagnosis of the embedding level of sustainability competencies in engineering education, both from the point of view of the teaching staff (what do they consider to be learned in "their" subjects) and the student body (what do they consider they have learned in their time at university), through ad hoc questionnaires. For this purpose, the authors have taken as references the Learning Objectives included in the document Education for Sustainable Development Goals: learning objectives [29], and the sustainability competencies defined in the Spanish university environment by the Executive Committee of the Conference of Rectors of Spanish Universities [33].

The three tools presented in this paper (ESM, questionnaire for teachers to develop the Degree Sustainability Presence Map, and questionnaire for students) focus on embedding sustainability competencies in engineering degrees. However, they are exportable to other disciplines, as has been demonstrated in the framework of the EDINSOST2-SDG project for the areas of economy and education.

The Sustainability Map is the tool required by the academics charged with designing university curricula and the Institutes of Education Sciences or Advisory Services-Teacher Training to ensure a correct embedding of sustainability in the design of the curriculum. This map is also the tool that teachers need for selecting which SDG-Learning Objectives 
can best be developed in their subjects, should there be no comprehensive design of the curriculum that considers ESD holistically.

According to the correspondence presented in Figure 1, when analyzing the SDGLearning Objectives we can observe that only $26.7 \%$ of them are related to all engineering degrees, and another $13.7 \%$ are related to some particular engineering degree. It is difficult to make a judgment on whether this number is appropriate or whether it should be higher. However, it is striking that in the document [29], for example, no learning objectives of the SDG2 (Hunger zero) or SDG14 (Life below water) related to any engineering degree have been defined, while on analysis of the SDG targets it is evident that engineering degrees undoubtedly contribute to these SDG. Agronomic and forestry engineering, for example, promote the improvement of agricultural productivity (Target 2.3, SDG2) and the resilience of food production systems (Target 2.4, SDG2). Different Engineering degrees can contribute to SDG2 through the design of appropriate technologies, the maintenance of genetic diversity (Target 2.5, SDG2) and access to information on markets and food reserves (Target 2.c, SDG2). In reference to SDG 14 (Life below water), marine technology ranges from physical and noise pollution (Target 14.1) to aquaculture, usual contents in agronomic engineering studies (Target 14.7). The management, restoration, and sustainable protection of marine and coastal ecosystems (Target 14.2), on the other hand, are part of the area of Civil Engineering. These are just some examples, but engineering degrees can definitely contribute much more to the SDG than what is proposed in the SDG-Learning Objectives [29].

This reflection leads us to believe that the UNESCO document "Education for Sustainable Development Goals: learning objectives" [29] may have a biased approach towards certain fields of education training traditionally linked to sustainable development, and may not consider in-depth what engineers can do to help in achieving the SDG, as professionals "fully aware of what is going on in society and who have the skills to deal with societal aspects of technologies", as Erik de Graaf states it [19].

For this reason, the ESM includes learning outcomes that have not been identified in the SDG-learning objectives. Thus, with the wealth of engineering knowledge, the ESM contributes to the achievement of ESD, completing the UNESCO document [29] to progress in ESD, including the perspective of engineering and technology, whose professionals should focus their work on and for the welfare of society [25,54].

From the ESM, two questionnaires have been designed: one for teachers and the other for students. The objective of the questionnaire for teachers is to make a diagnosis and quantitively measure the real level of embedding of ESD in a curriculum and/or a subject. This questionnaire enables a self-diagnosis to be carried out, facilitates knowledge of which key sustainability competencies are not being addressed, decisions about which ones should be reinforced. It also enables decision-making on an effective distribution of sustainability competencies in different subjects and at different levels.

The questionnaire designed for students enables the quantitative measurement of the perception that students have about their own learning in sustainability. Therefore, the comparison between the results of the sustainability presence map and the responses of the students of a certain course or a certain degree will help to determine exactly to what extent the curriculum achieves its ESD objectives and whether the graduates are effectively trained in sustainability. As well as the questionnaire for teachers, the student questionnaire enables the identification of the learning outcomes that are not being developed in the curriculum and possible areas for improvement.

Among the future lines of work, and in order to facilitate the analysis of sustainability embedding in a curriculum and subsequent decision-making, the authors consider it necessary to develop a methodology that enables the results obtained in both questionnaires (teachers and students) to be compared, in order to quantify to what extent the curriculum effectively achieves its planned objectives. In the EDINSOST1 project, a methodology was presented to quantify the presence of sustainability learning outcomes in the curriculum $[47,48]$ which, together with the results of the questionnaire presented in this 
work, can be employed with minor adaptations. The EDINSOST1 project also presented a methodology aimed at analyzing student responses [51,52], which can be used effectively together with the questionnaire proposed in this paper.

A further line of research is to explore the embedding of sustainability in the Final Degree Project (FDP). In the FDP, students must demonstrate that they are capable of integrating all the knowledge acquired during their studies in order to solve a complex problem and suggest a sustainable proposal. The EDINSOST2-SDG project is currently working on the design of a methodology to enable students to integrate sustainability in their FDP. A preliminary preview of the results can be found in [55].

In the EDINSOST2-SDG project, the three tools described in this work are currently being used in three Spanish universities: the Polytechnic University of Madrid (UPM), the Universitat Politècnica de Catalunya (UPC-BarcelonaTech) and the University of the Basque Country (UPV/EHU). The analysis is being conducted in four degrees: Degree in Telecommunications Engineering, Degree in Computer Engineering, Degree in Industrial Technology Engineering, and Degree in Industrial Design and Product Development. Students are asked to complete the questionnaire at the end of the first and last year of all the degrees involved, so that at the end of the project (2022) they are able to analyze the evolution in the perception of the students regarding their sustainability competencies. The Sustainability Presence Map of each degree is being built from the teacher questionnaire. This map is not static since it changes as teachers train in ESD and in turn leads to changes to their subjects. To progress in the embedding of ESD in the curriculum, the EDINSOST2SDG project has designed an ESD training workshop provided for every course and in all Degrees involved in the project. The teachers attending this workshop are trained in ESD and learn to design activities for integrating the SDG into their subjects on the basis of the ESM learning outcomes. The curriculum of the degrees in which these subjects are taught are thereby progressively improving sustainability embedding.

University teachers need ESD training in order for the university to make an effective contribution to the achievement of the integration of the SDG. This training should be aimed not only at the improvement of their sustainability competencies, but also to help them embed the SDG in the subjects they teach. The ESM is an ideal tool for achieving this goal. It is necessary for universities to offer this type of training to their faculty, as it is the only way to achieve a real embedding of ESD in the curricula.

\section{Conclusions}

To advance in the "2030 for SDG" [13] framework, it is essential to design tools that enable a diagnosis of the degree of integration of sustainability competencies in higher education, with the aim of guaranteeing the acquisition of these competences by graduate students. The tools should be easy to use, implement and export to different study areas.

In this paper, we have presented three tools that enable ESD embedding in engineering curricula. These tools are needed for the academics responsible for designing university curricula as well as for training the trainers, in order to introduce sustainability into the curriculum effectively. They are also the tools that teachers need to enable them to choose which SDG-learning objectives are most appropriate for developing in their subjects.

The first tool, the Engineering Sustainability Map, facilitates the definition and distribution of ESD-related learning outcomes within the curriculum. The second tool the Sustainability Presence Map of the degree, based on the sustainability learning outcomes that are developed in the subjects. The third tool, the questionnaire for students, enables us to quantitatively measure the perception of students about their own learning in sustainability. Comparison of the perception of students with the sustainability presence maps is the first step to determine to what extent a curriculum effectively achieves its ESD objectives; a proper learning assessment will confirm such effectiveness. To achieve the ESD integration transformative learning approaches that requires a whole pedagogical transformation in engineering education are needed [56]. 
Comparing the learning outcomes of the Engineering Sustainability Map with the SDG-learning objectives [29], it can be established that just over a quarter of the SDGlearning objectives are related to all engineering degrees, and two SDG (SDG 2, SDG 14) have no appropriate learning objective to be developed in any engineering degree. To address this issue, the Engineering Sustainability Map includes some learning outcomes that are unrelated to the SDG-learning objectives, but which are related to the SDG. Thus, the Engineering Sustainability Map completes the UNESCO document [29] and helps in the achievement of the SDG, including from both the engineering and technology point of view.

As further work, the EDINSOST2-SDG project is currently developing a methodology aimed at comparing the results obtained from teacher and student questionnaires to quantify the extent to which a curriculum meets its ESD objectives. With the same purpose, the authors will continue working on embedding sustainability in the Final Degree Projects. The tools described in this work have been implemented in several Engineering Degrees of three Spanish universities, and a final analysis of the results is planned in 2022, in the final phase of EDINSOST2-SDG project. The results of this implementation in these Spanish universities as well as other Higher Education Institutions worldwide will be used for the continuous improvement the three tools.

The results of this work are aligned with the work done for the Business administration and Management degrees [57] of the EDINSOST2-SDG project, which shows that the results of the project can be applied to any degree with little adaptation of the tools

We believe that the results of this study will be useful as one of the many avenues for improving the "Education for Sustainable Development: Towards the Achievement of the SDG" [13] in universities around the world, as well for helping academics in charge of graduate studies and for teachers seeking to adapt teaching-learning methodologies as a contribution to the SDG. Furthermore, and most importantly, for empowering their students to tackle the challenges of the 21st century.

Author Contributions: Conceptualization, F.S.-C. and J.S.; methodology, F.S.-C., J.S., J.C., D.L., C.M., G.T. and E.V.; validation, F.S.-C., J.S., G.B., P.B., J.C., V.G.G., B.L., D.L., C.M., R.M., E.S.d.C., B.S., G.T. and E.V.; formal analysis, F.S.-C., J.S., J.C., D.L., C.M., G.T. and E.V.; investigation, F.S.-C., J.S., G.B., P.B., J.C., V.G.G., B.L., D.L., C.M., R.M., E.S.d.C., B.S., G.T. and E.V.; resources, F.S.-C. and J.S.; data curation, F.S.-C., J.S. and G.T.; writing-original draft preparation, F.S.-C., J.S., G.B., P.B., J.C., V.G.G., B.L., D.L., C.M., R.M., E.S.d.C., B.S., G.T. and E.V.; writing-review and editing, F.S.-C., J.S. and G.T.; visualization, F.S.-C., J.S. and G.T.; supervision, F.S.-C. and J.S.; project administration, F.S.-C., J.S. and G.T.; funding acquisition, F.S.-C. and J.S. All authors have read and agreed to the published version of the manuscript.

Funding: This work was supported by the Spanish Ministerio de Ciencia, Innovación y Universidades, the Spanish Agencia Estatal de Investigación (AEI), and the Fondo Europeo de Desarrollo Regional (FEDER), from study design to submission, under grant number RTI2018-094982-B-I00.

Institutional Review Board Statement: Not applicable.

Informed Consent Statement: Not applicable.

Acknowledgments: The authors acknowledge all the project team members.

Conflicts of Interest: The authors declare no conflict of interest.

\section{References}

1. Grindsted, T.S.; Holm, T. Thematic development of declarations on Sustainability in Higher Education. Environ. Econ. 2012, 1, 32-39. [CrossRef]

2. Lozano, R.; Ceulemans, K.; Alonso-Almeida, M.; Huisingh, D.; Lozano, F.; Waas, T.; Huge, J. A review of commitment and implementation of sustainable development in higher education: Results from a worldwide survey. J. Clean. Prod. 2015, 108, 1-18. [CrossRef]

3. Wright, T. The evolution of sustainability declarations in higher education. In Higher Education and the Challenge of Sustainability; Corcoran, P., Wals, A., Eds.; Kluwer Academic Publishers: Dordrecht, The Netherlands, 2004; pp. 7-14. 
4. Miñano, R.; Uribe, D.; Moreno-Romero, A.; Yáñez, S. Embedding Sustainability Competences into Engineering Education. The Case of Informatics Engineering and Industrial Engineering Degree Programs at Spanish Universities. Sustainability 2019, 11, 5832. [CrossRef]

5. SDSN Australia/Pacific. Getting Started with the SDGs in Universities: A Guide for Universities, Higher Education Institutions, and the Academic Sector. Australia, New Zealand and Pacific Edition. Sustainable Development Solutions NetworkAustralia/Pacific, Melbourne. 2017. Available online: http://ap-unsdsn.org/wp-content/uploads/University-SDG-Guide_web. pdf (accessed on 13 May 2021).

6. UNU. United Nations University Nagoya Declaration on Higher Education for Sustainable Development. International Conference on Higher Education for Sustainable Development: Higher Education Beyond. 2014. Available online: https: / / sustainabledevelopment.un.org/index.php?page=view\&type=111\&nr=5864\&menu=35 (accessed on 13 May 2021).

7. Wright, T. University presidents' conceptualizations of sustainability in higher education. Int. J. Sustain. High. Educ. 2010, 11, 61-73. [CrossRef]

8. Yáñez, S.; Uruburu, Á.; Moreno, A.; Lumbreras, J. The sustainability report as an essential tool for the holistic and strategic vision of higher education institutions. J. Clean. Prod. 2019, 207, 57-66. [CrossRef]

9. UN. Transforming Our World: The 2030 Agenda for Sustainable Development. 2015. Available online: https://undocs.org/en/ A/RES/70/1 (accessed on 13 May 2021).

10. SDSN. Accelerating Education for the SDGs in Universities: A Guide for Universities, Colleges, and Tertiary and Higher Education Institutions. New York: Sustainable Development Solutions Network. 2020. Available online: https://www.unsdsn. org/accelerating-education-for-the-sdgs-in-univerisities (accessed on 13 May 2021).

11. Kates, R.W.; Clark, W.C.; Corell, R.; Hall, J.M.; Jaeger, C.C.; Lowe, I.; McCarthy, J.J.; Schellnhuber, H.J.; Bolin, B.; Dickson, N.M.; et al. Sustainability science. Science 2001, 292, 641-642. [CrossRef]

12. Vilches, A.; Gil Pérez, D. Ciencia de La Sostenibilidad: ¿Una Nueva Disciplina o Un Nuevo Enfoque Para Todas Las Disciplinas? Rev. Iberoam. Educ. 2015, 69, 39-60. [CrossRef]

13. UNESCO. Framework for the Implementation of Education for Sustainable Development (ESD) beyond 2019. In Proceedings of the 40th UNESCO General Conference, Paris, France, 12-27 November 2019. Available online: https://unesdoc.unesco.org/ notice?id=p::usmarcdef_0000370215 (accessed on 28 October 2021).

14. Buckler, C.; Creech, H. Shaping the Future We Want: UN Decade of Education for Sustainable Development (2005-2014), Final Report; UNESCO: Paris, France, 2014; Available online: https:/ / unesdoc.unesco.org/ark:/48223/pf0000230302 (accessed on 13 May 2021).

15. Lazzarini, B.; Pérez-Foguet, A.; Boni, A. Key characteristics of academics promoting Sustainable Human Development within engineering studies. J. Clean. Prod. 2018, 188, 237-252. [CrossRef]

16. Mulder, K.F.; Segalàs, J.; Ferrer-Balas, D. How to educate engineers for/in sustainable development: Ten years of discussion, remaining challenges. Int. J. Sustain. High. Educ. 2012, 13, 211-218. [CrossRef]

17. Neubauer, C.; Calame, M. Global Pressing Problems and the Sustainable Development Goals. In Higher Education in the World 6. Towards a Socially Responsible University: Balancing the Global with the Local; Global University Network for Innovation (GUNI): Girona, Spain, 2017; pp. 68-77. Available online: http://www.guninetwork.org/files/download_full_report.pdf (accessed on 28 October 2021).

18. Wals, A.E. Sustainability in higher education in the context of the UN DESD: A review of learning and institutionalization processes. J. Clean. Prod. 2014, 62, 8-15. [CrossRef]

19. Segalàs, J.; Ferrer-Balas, D.; Mulder, K.F. What do engineering students learn in sustainability courses? The effect of the pedagogical approach. J. Clean. Prod. 2010, 18, 275-284. [CrossRef]

20. De Wit, H.; Leask, B. Reimagining the Curriculum for the 21st Century. In Higher Education in the World 6. Towards a Socially Responsible University: Balancing the Global with the Local; Global University Network for Innovation, GUNI: Girona, Spain, 2017; pp. 222-235. Available online: http://www.guninetwork.org/files/download_full_report.pdf (accessed on 28 October 2021).

21. Harpe, B.; Thomas, I. Curriculum change in universities: Conditions that facilitate education for sustainable development. $J$. Educ. Sustain. Dev. 2009, 3, 75-85. [CrossRef]

22. CTI. Comission des Titres d'Ingénieur. Restitution des FOCUS d'Audit 2016-2017; Comission des Titres d'Ingénieur: Paris, France, 2017. Available online: https://www.cti-commission.fr/wp-content/uploads/2017/03/FOCUS_R2017_Restitution_201702.pdf (accessed on 13 May 2021).

23. Graham, R. The Global State of the Art in Engineering Education; Massachusetts Institute of Technology (MIT): Cambridge, MA, USA, 2018. Available online: https://es.scribd.com/document/387373859/mit-neet-globalstateengineeringeducation2018-pdf (accessed on 13 May 2021).

24. Lozano, F.J.; Lozano, R. Developing the curriculum for a new Bachelor's degree in engineering for sustainable development. J. Clean. Prod. 2014, 64, 136-146. [CrossRef]

25. Cech, E.A. Culture of Disengagement in Engineering Education? Sci. Technol. Hum. Values 2014, 39, 42-72. [CrossRef]

26. Cech, E.A.; Sherick, H.M. Depoliticization and the Structure of Engineering Education. In International Perspectives on Engineering Education. Philosophy of Engineering and Technology; Christensen, S., Didier, C., Jamison, A., Meganck, M., Mitcham, C., Newberry, B., Eds.; Springer: Cham, Switzerland, 2015. Available online: https://doi-org.recursos.biblioteca.upc.edu/10.1007/978-3-319-16 169-3_1 (accessed on 28 October 2021). 
27. Núñez, A.M.; Mayhew, M.J.; Shaheen, M.; Dahl, L.S. Let's Teach Computer Science Majors to Be Good Citizens. The Whole World Depends on It. Edsurge. 2021. Available online: https:/ / www.edsurge.com/news/2021-03-15-let-s-teach-computer-sciencemajors-to-be-good-citizens-the-whole-world-depends-on-it (accessed on 13 May 2021).

28. Segalàs, J.; Sánchez-Carracedo, F. The EDINSOST project: Improving Sustainability Education in Spanish Higher Education. In Proceedings of the 19th ERSCP-European Roundtable for Sustainable Consumption and Production, Barcelona, Spain, 15-18 October 2019; pp. 217-240. Available online: https://upcommons.upc.edu/bitstream/handle/2117/176645/ERSCP_2019 _published.pdf?sequence=1\&isAllowed $=y$ (accessed on 13 May 2021).

29. UNESCO. Education for Sustainable Development Goals: Learning Objectives. 2017. Available online: https:/ / unesdoc.unesco. org/ark:/48223/pf0000247444 (accessed on 13 May 2021).

30. De Haan, G. The development of ESD-related competencies in supportive institutional frameworks. Int. Rev. Educ. 2010, 56, 315-328. [CrossRef]

31. Rieckmann, M. Future-oriented higher education: Which key competencies should be fostered through university teaching and learning? Futures 2012, 44, 127-135. [CrossRef]

32. Wiek, A.; Withycombe, L.; Redman, C.L. Key competences in sustainability: A reference framework for academic program development. Sustain. Sci. 2011, 6, 203-218. [CrossRef]

33. CRUE. Directrices para la Sostenibilización Curricular. Available online: https://www.crue.org/wp-content/uploads/2020/02/ Directrices_Sosteniblidad_Crue2012.pdf (accessed on 13 May 2021).

34. Barcelona Declaration. In Proceedings of the International Conference on Engineering Education for Sustainable Development, Barcelona, Spain, 27-29 October 2004. Available online: https:/ / eesd15.engineering.ubc.ca/declaration-of-barcelona/ (accessed on 13 May 2021).

35. ABET. Criteria for Accrediting Engineering Programs. Accreditation Board for Engineering and Technology. Available online: https:/ / www.abet.org/accreditation/accreditation-criteria/criteria-for-accrediting-engineering-programs-2020-2021/ (accessed on 13 May 2021).

36. CEAB (Canadian Engineering Accreditation Board). Accreditation Criteria and Procedures. 2017. Available online: https: / / engineerscanada.ca/sites/default/files/accreditation-criteria-procedures-2017.pdf (accessed on 13 May 2021).

37. ENAEE (European Network for Accreditation of Engineering Education). EUR-ACE Framework Standards. 2018. Available online: https:/ / www.enaee.eu/eur-ace-system/standards-and-guidelines/\#standards-and-guidelines-for-accreditation-ofengineering-programmes (accessed on 13 May 2021).

38. Barrón, A.; Navarrete, A.; Ferrer-Balas, D. Sostenibilización curricular en las universidades españolas. ¿ha llegado la hora de actuar? Rev. Eureka Sobre Enseñanza Divulg. Cienc. 2010, 7, 388-399. [CrossRef]

39. Moreso, J.J.; Casadesús, M. Preparing the Global Citizenry, Implications for the Curriculum. In Higher Education in the World 6. Towards a Socially Responsible University: Balancing the Global with the Local; Global University Network for Innovation (GUNI): Girona, Spain, 2017; pp. 181-193. Available online: http:/ / www.guninetwork.org/files/download_full_report.pdf (accessed on 13 May 2021).

40. Tilbury, D. Higher education for sustainability: A global overview of commitment and progress. In Higher Education in the World 4. Higher Education's Commitment to Sustainability from Understanding to Action; Global University Network for Innovation (GUNI): Girona, Spain, 2011; pp. 18-28.

41. Colby, A.; Sullivan, W.M. Ethics Teaching in Undergraduate Engineering Education. J. Eng. Educ. 2008, 97, 327-338. [CrossRef]

42. François, E.J. Preparing Glocal Citizenry, Implications for the Curriculum. In Higher Education in the World 6. Towards a Socially Responsible University: Balancing the Global with the Local; Global University Network for Innovation (GUNI): Girona, Spain, 2017; pp. 194-208. Available online: http:/ / www.guninetwork.org/files/download_full_report.pdf (accessed on 13 May 2021).

43. Segalàs, J. Engineering Education for a Sustainable Future. Ph.D. Thesis, Universitat Politècnica de Catalunya, Barcelona, Spain, 2009. Available online: https:/ / upcommons.upc.edu/handle/2117/93241 (accessed on 13 May 2021).

44. Sánchez-Carracedo, F.; Soler, A.; Martín, C.; López, D.; Ageno, A.; Cabré, J.; García, J.; Aranda, J.; Gibert, K. Competency Maps: An Effective Model to Integrate Professional Competencies Across a STEM Curriculum. J. Sci. Educ. Technol. 2018, 27, 448-468. [CrossRef]

45. Sánchez-Carracedo, F.; Segalàs, J.; Vidal, E.; Martín, C.; Climent, J.; López, D.; Cabré, J. Improving engineering educators' sustainability competencies by using competency maps: The EDINSOST project. Int. J. Eng. Educ. 2018, 34, $1527-1537$.

46. Miller, G.E. The assessment of clinical skills/competence/performance. Acad. Med. 1990, 65, S63-S67. [CrossRef]

47. Sánchez-Carracedo, F.; Moreno-Pino, F.-M.; Sureda, B.; Antúnez, M.; Gutiérrez, I.A. Methodology to Analyze the Presence of Sustainability in Engineering Curricula. Case of Study: Ten Spanish Engineering Degree Curricula. Sustainability 2019, 11, 4553. [CrossRef]

48. Sánchez-Carracedo, F.; Sureda, B.; Moreno-Pino, F.M. Analysis of sustainability presence in Spanish higher education. Int. J. Sustain. High. Educ. 2020, 21, 393-412. [CrossRef]

49. Meul, M.; Nevens, F.; Reheul, D. Validating sustainability indicators: Focus on ecological aspects of Flemish dairy farms. Ecol. Indic. 2009, 9, 284-295. [CrossRef]

50. Bockstaller, C.; Girardin, P. How to validate environmental indicators. Agric. Syst. 2003, 76, 639-653. [CrossRef]

51. Sánchez-Carracedo, F.; Sureda, B.; Moreno-Pino, F.M.; Romero-Portillo, D. Education for Sustainable Development in Spanish Engineering Degrees. Case Study J. Clean. Prod. 2021, 294, 126322. [CrossRef] 
52. Sánchez-Carracedo, F.; Moreno-Pino, F.M.; Romero-Portillo, D.; Sureda, B. Education for Sustainable Development in Spanish University Education Degrees. Sustainability 2021, 13, 1467. [CrossRef]

53. Sánchez-Carracedo, F.; Álvarez, M.J.; Barrón, A.; Caballero, D.; López, E.; Muñoz, J.M.; Lugo-Muñoz, M.; Sureda, B.; Vidal, E.; Vidal, S. Elaboración de un Cuestionario para Evaluar el nivel de Sostenibilidad de los Estudiantes de Grados en Ingeniería. In Actas de las XXIV Jornadas Sobre la Enseñanza Universitaria de la Informática; Asociación de Enseñantes Universitarios de la Informática: Barcelona, Spain, 2018; pp. 141-148. Available online: https://upcommons.upc.edu/bitstream/handle/2117/12173 4/470-2899-1-PB.pdf?sequence=1\&isAllowed=y (accessed on 13 May 2021).

54. Tejedor, G.; Rosas-Casals, M.; Segalas, J. Patterns and Trends in Engineering Education in Sustainability. Int. J. Sustain. High. Educ. 2019, 20, 360-377. [CrossRef]

55. Sánchez-Carracedo, F.; López, D.; Martín, C.; Vidal, E.; Cabré, J.; Climent, J. The Sustainability Matrix: A Tool for Integrating and Assessing Sustainability in the Bachelor and Master Theses of Engineering Degrees. Sustainability 2020, 12, 5755. [CrossRef]

56. Tejedor, G.; Segalas, J.; Barrón, A.; Fernández-Morilla, M.; Fuertes, M.T.; Ruiz-Morales, J.; Gutiérrez, I.; García-González, E.; Aramburuzabala, P. and Hernández, A. Didactic Strategies to Promote Competencies in Sustainability. Sustainability 2019, 11, 2086. [CrossRef]

57. Gil-Doménech, D.; Magomedova, N.; Sánchez-Alcázar, E.J.; Lafuente-Lechuga, M. Integrating Sustainability in the Business Administration and Management Curriculum: A Sustainability Competencies Map. Sustainability 2021, 13, 9458. [CrossRef] 